\title{
Does oil palm agriculture help alleviate poverty? A multidimensional counterfactual assessment of oil palm development in Indonesia
}

\section{Authors:}

Truly Santika ${ }^{1,2,3,4, *}$, Kerrie A. Wilson ${ }^{1,5}$, Sugeng Budiharta ${ }^{1,6}$, Elizabeth A. Law ${ }^{1,7}$, Tun Min Poh ${ }^{2}$, Marc Ancrenaz ${ }^{2,3,8}$, Matthew Struebig ${ }^{4}$ \& Erik Meijaard ${ }^{1,2,3,4}$

\section{Affiliations}

1 ARC Centre of Excellence for Environmental Decisions, The University of Queensland, Brisbane, QLD, Australia

2 Borneo Futures, Brunei Darussalam

3 IUCN Oil Palm Task Force

4 Durrell Institute of Conservation and Ecology (DICE), University of Kent, Canterbury, CT2 7NR, United Kingdom

5 Institute for Future Environments, Queensland University of Technology, Brisbane, Australia

6 Purwodadi Botanic Garden-Indonesian Institute of Sciences, JI. Surabaya-Malang Km. 65, Pasuruan, Jawa Timur, Indonesia

7 Norwegian Institute for Nature Research (NINA), Trondheim, Norway

8 Kinabatangan Orang-utan Conservation Programme, Sandakan, Sabah, Malaysia

\section{* Corresponding author:}

Truly Santika

E-mail: trulysantika@gmail.com 


\section{Abstract}

Palm oil producing countries regularly promote the positive impact of palm oil agriculture on poverty alleviation, despite limited evidence about the contribution of this crop on village well-being. Past evaluations that quantify the social impact of oil palm are dominated by localized studies, which complicate the detection of generalizable findings. Moreover, only a few of these evaluations are based on rigorous case-control studies, which limits the robustness of the conclusions. Here we examined the association between the development of oil palm plantations and change in objective or material wellbeing between 2000 and 2014 across villages in Kalimantan, Indonesian Borneo. We applied a matching method to evaluate the impacts of oil palm plantations across different aspects of well-being, accounting for varying time delays in the accrual and realization of benefits after plantation development. Our study reveals that the social impacts of oil-palm plantations are not uniformly positive, nor negative, and have varied systematically with biophysical locations and baseline socioeconomic conditions of nearby communities prior to oil palm development. Plantations developed in villages with low to moderate forest cover, in which the majority of communities already relied on market-oriented livelihoods, were associated with improved socioeconomic well-being compared to villages without oil palm development. However, we found the opposite for plantations developed in remote villages with higher forest cover, in which the majority of communities previously relied on subsistence-based livelihoods. Overall, oil palm growing villages were more associated with reduced rate of improvement of social and environmental well-being compared to villages without oil palm development, regardless of location and baseline community livelihoods. Our findings highlight an urgent need for careful evaluation and planning in the development of oil palm agriculture in remote forested areas. For oil palm regions that have been developed, our study shows that unsustainable livelihoods, increased socioeconomic disparity, and environmental issues remain major challenges.

Keywords: human well-being; impact evaluation; Indonesia; landscape analysis; multidimensional poverty; oil palm 


\section{Introduction}

In recent decades there has been an enormous increase in the demand for oils and fats worldwide due to growing populations and wealth: the global consumption rose from 80 million to 213 million tonnes between 1990 and 2015 (FAO 2016). Palm oil production has boomed in response to this demand, with the global production increasing from 14 million to 63 million tonnes over the same period (FAO 2016). Globally, oil palm plantations have expanded from 6 to 18 million hectares over the last two decades, and now account for $0.4 \%$ of the world's permanent cropland (FAO 2016). Indonesia and Malaysia is currently the world's leading palm oil producer, supplying approximately more than $80 \%$ of the commodity globally (FAO 2016). In Indonesia, plantations have predominantly been developed in Sumatra and Kalimantan (Indonesian Borneo), with rapid expansion in recent decades (Fig. A1 and A2 in Appendix A; Directorate General of Estate Crops Indonesia 2015). Prior to 2000, oil palm plantations were developed mainly on barren land (e.g. burnt-over areas) or on established farmland, but conversion of forest to plantations has become increasingly common in recent years due to increasingly scarce non-forest land for agriculture (Fig. A3a; Santika et al. 2015; Gaveau et al. 2016b). Agricultural expansion into forested areas could have profound impacts on local and traditional communities who depend highly on forest produce and income (Sheil et al. 2009).

In 2017, the Indonesian oil palm industry was estimated to employ 3.8 million people (Directorate General of Estate Crops 2017), ca. 2.4\% of the total Indonesian work force (Allen 2016), and the Indonesian government increasingly promotes oil palm cultivation as a way to alleviate poverty and advance development in remote forested landscapes (Cooke 2012; Potter 2012; Li 2016). Other developing and emerging countries, such as Brazil, Peru, Colombia, Nigeria, Gabon, Ghana, and Rwanda, are following similar steps (Villela et al. 2014; Byerlee et al. 2017; Meijaard et al. 2018). However, despite driving macro-level economic growth in many tropical countries, there are mixed reports about the social impact of oil palm agriculture on the life of communities in production areas. While positive impacts on household income and consumption, as well as local development and employment have been observed, numerous social and environmental costs of oil palm have also been reported (reviewed in Table B1 in Appendix B). For example, in some areas the promised benefits and compensation of oil palm cultivation has not reached all smallholders (Sheil et al. 2009; Rist et al. 2010), and consultation with indigenous peoples has not always occurred (Colchester et al. 2006), leading to escalating conflicts with local people (Abram et al. 2017; Wakker et al. 2004). Expansion of the oil palm industry in some areas has increased income benefits mainly among wealthy farmers and skilled migrants while marginalising others, leading to social disparities (Obidzinski et al. 2012, 2014; Zen et al. 2016). In addition, depletion of land and water resources, and deterioration of air and water quality due to unsustainable oil palm practices have further burdened communities in some locations (Phalan 2009; Sheil et al. 2009; Wells et al. 2016).

Past evaluations of the social impact of industrial-scale oil palm plantations in developing countries have typically been appraised in localized studies, either within district, province or state (Table B1). A few exceptions are Obidzinski and colleagues (2012) who studied the perceptions of the social impact of oil palm plantations among three indigenous communities in the province of West Kalimantan, Papua, and West Papua, and Castiblanco, Etter and Ramirez (2015) who studied the social impact of oil palm across municipalities in Colombia. Furthermore, only a few of these past evaluations were based on rigorous case-control studies (Table B1). In complex social and environmental settings, there are many factors other than the intervention that may cause or moderate change, so quantifying the impact of an intervention is impossible without identifying an appropriate comparator or counterfactual of what would have happened in the absence of that intervention (Ferraro 2009). Additionally, studies that apply a counterfactual analysis approach for evaluating the social impact of oil palm are mostly based on data from Sumatra, and geographically biased around transmigration areas in the province of Riau and Jambi (e.g. Alwarritzi et al. 2015; Euler et al. 2017; Gatto et al. 2017; Krishna et al. 2017) (Table B1). These provinces are not only recognized as the hotspots of Indonesia's recent oil palm boom, but also the hotspots of transmigration programs during the New Order regime in 1965-1998 (the period from PraPelita to Pelita IV), when at least 680,000 transmigrants from Java relocated in both provinces combined 
(Junaidi 2012; Palupi et al. 2017). Thus, the baseline socioeconomic context and socio-political history of the oil palm growing areas associated with these studies likely have limited transferability of the resulting conclusions to other oil palm areas where recent migration was considered to be less prevalent prior to oil palm developments, such as in many parts of Kalimantan and Papua.

Our literature review (Table B1) highlights substantial variability of the social impact of oil palm among locations with different biophysical characteristics and baseline socioeconomic conditions of communities. There is therefore a clear need for greater synthesis to detect generalizable findings, which can come from landscape-based assessment over broad areas. Understanding variation in how social benefits accrue from oil palm developments is critical to help identify opportunities to improve policy implementation and ultimately improve outcomes for village communities (Hodbod \& Tomei 2013; Blaber-Wegg et al. 2015). Therefore, a robust evaluation of the impact of the oil palm industry requires analyses of (1) changes in indicators of well-being due to the oil palm development compared to the counterfactual condition without oil palm, (2) trends over time to account for potential delays in the accrual and realization of benefits, and (3) multiple sites over broad areas to detect variations in the impacts of oil palm across different baseline biophysical and community socioeconomic conditions.

Here we assessed the impact of oil palm plantation developments on changes in objective or material aspects of well-being between 2000 and 2014 across villages in Kalimantan, Indonesian Borneo. Oil palm plantations mainly include industrial scale plantations developed within concession boundaries (including smallholder plantings operated as part of the nucleus estate system, i.e. cooperation between company plantations and smallholders in terms of capital and labour supply) and to a smaller extent independent smallholders (see Fig. A1a). We note that industrial scale plantations often spatially coincide with independent smallholder plantations (Euler et al. 2016; Jelsma et al. 2017), and that our results should be interpreted as an overall effect of oil palm development, across different production scales, on village well-being. As plantations require some time to mature, be harvested, and provide economic benefits (Rist et al. 2010), we investigated the change of well-being following 2-3, 6-8, and 11-14 years after initial plantation development within the village administrative unit. We defined well-being across five dimensions: (1) basic (i.e. living conditions), (2) physical (i.e. infrastructure), (3) financial (i.e. income support), (4) social (i.e. security and social equity), and (5) environmental (i.e. prevention of natural hazards). We used 17 indicators from the village level dataset Potensi Desa (PODES) as proxies for these aspects of well-being (Table 1). PODES data were collected by the Bureau of Statistics Indonesia (BPS) roughly every three years between 2000 and 2014 (BPS 2015), providing the best data option for this broad-scale analysis. We recognise that more subjective, non-material, indicators exist to measure human well-being (Costanza et al. 2007; Daniel et al. 2012). However, these are difficult to aggregate at the village-level and are not available within the PODES dataset.

The effect of oil palm plantations on village well-being was assessed based on a counterfactual analysis: comparing what actually happened and what would have happened in the absence of the oil palm plantations. For this counterfactual, we employed a matching method (Dehejia \& Wahba 2002) to select a set of control villages outside oil palm growing areas that exhibited the same baseline characteristics as villages within the oil palm areas. By doing so, we controlled for variables that could confound the analysis, such as socio-political factors, accessibility, agricultural productivity, and recent climate, as well as baseline village well-being and primary livelihoods (Table 2). We explored how the effect of oil palm plantations varied across different village primary livelihoods prior to plantation development, which includes (1) subsistence-based livelihoods, i.e. swidden farming of dryland rice (intercropped with banana, maize, and cassava, and typically supplemented by market exchange for forest and/or agroforest products) and inland fishing (Budiharta et al. 2016), and (2) market-oriented livelihoods, including polyculture plantations (e.g. coffee, rubber, oil palm, coconut), horticulture, aquaculture, agricultural services, and non-agricultural sectors. 
Table 1. PODES indicators used as proxies for five dimensions of well-being: basic, physical, financial, social, and environmental. Variable $w_{k}$ denotes the directional effect of the change in indicator $k$ that defines improvement in well-being. If $w_{k}=1$, then positive change (i.e. an increase) in indicator $k$ represents improvement in well-being. If $w_{k}=-1$, then negative change (i.e. a reduction) in indicator $k$ represents improvement in well-being.

\begin{tabular}{|c|c|c|c|c|}
\hline $\begin{array}{l}\text { Dimension of } \\
\text { well-being }\end{array}$ & $\begin{array}{l}\text { PODES } \\
\text { indicator } \\
(k)\end{array}$ & Description & $w_{k}$ & Response \\
\hline \multirow{5}{*}{$\begin{array}{l}\text { Basic } \\
\text { (Living } \\
\text { conditions) }\end{array}$} & POOR & $\begin{array}{l}\text { Proportions of households with poor } \\
\text { housing conditions } *\end{array}$ & -1 & Continuous \\
\hline & ELCT & $\begin{array}{l}\text { Proportions of households with } \\
\text { electricity } *\end{array}$ & 1 & Continuous \\
\hline & COOK & Cooking fuel for majority of households & -1 & $\begin{array}{l}\text { Categorical ( } 1=\text { electricity or } \\
\text { liquefied petroleum gas (LPG), } \\
2=\text { kerosene, } 3=\text { wood/others) }\end{array}$ \\
\hline & TOLT & $\begin{array}{l}\text { Toilet facilities for majority of } \\
\text { households }\end{array}$ & -1 & $\begin{array}{l}\text { Categorical (1=own toilet, } \\
2=\text { joint toilet, } 3=\text { public toilet, } \\
4=\text { non-toilet) }\end{array}$ \\
\hline & MLNT & $\begin{array}{l}\text { Child malnutrition incidence in the last } \\
\text { year }+\end{array}$ & -1 & Continuous \\
\hline \multirow{3}{*}{$\begin{array}{l}\text { Physical } \\
\text { (Infrastructure) }\end{array}$} & HEAL & Distance to nearest healthcare facility & -1 & Continuous \\
\hline & $\mathrm{PSCH}$ & Distance to nearest primary school & -1 & Continuous \\
\hline & $\mathrm{SSCH}$ & Distance to nearest secondary school & -1 & Continuous \\
\hline \multirow[t]{3}{*}{$\begin{array}{l}\text { Financial } \\
\text { (Income support) }\end{array}$} & COOP & $\begin{array}{l}\text { Number of active village cooperative } \\
\text { schemes or other schemes } \ddagger\end{array}$ & 1 & Continuous \\
\hline & CRDT & $\begin{array}{l}\text { Number of credit facilities for farmers } \\
\text { or communities } \ddagger\end{array}$ & 1 & Continuous \\
\hline & SIND & $\begin{array}{l}\text { Number of small industries }(<20 \\
\text { employees }) \ddagger\end{array}$ & 1 & Continuous \\
\hline \multirow{3}{*}{$\begin{array}{l}\text { Social } \\
\text { (Security and } \\
\text { social equity) }\end{array}$} & CNFL & $\begin{array}{l}\text { Frequency of conflicts among } \\
\text { communities in the last year }\end{array}$ & -1 & Continuous \\
\hline & AGLB & $\begin{array}{l}\text { Proportion of families with agricultural } \\
\text { wage labourers } * *\end{array}$ & -1 & Continuous \\
\hline & SUIC & Suicidal rates in the last year ${ }^{\dagger}$ & 1 & Continuous \\
\hline \multirow{3}{*}{$\begin{array}{l}\text { Environmental } \\
\text { (Natural hazard } \\
\text { prevention) }\end{array}$} & WPOL & Water pollution over the last 3 years & -1 & $\begin{array}{l}\text { Categorical (1=none, } 2=\text { mild, } \\
3=\text { severe) }\end{array}$ \\
\hline & APOL & Air pollution over the last 3 years & -1 & $\begin{array}{l}\text { Categorical ( } 1=\text { none, } 2=\text { mild, } \\
3=\text { severe) }\end{array}$ \\
\hline & FLOD & $\begin{array}{l}\text { Frequency of floods and landslides over } \\
\text { the last } 3 \text { years }\end{array}$ & -1 & Continuous \\
\hline
\end{tabular}

† per 1000 people, $\ddagger$ per 100 households, * of total households, ** of total agricultural families 
Table 2. Variables used to assess oil-palm efficacy in improving village well-being.

\begin{tabular}{|c|c|c|c|}
\hline Variable & Description (Static/Dynamic ${ }^{\S}$ ) & Type (Scale) & Data source \\
\hline \multicolumn{4}{|c|}{ SOCIO-POLITICAL } \\
\hline$K A B U$ & $\begin{array}{l}\text { Regency (kabupaten) boundaries } \\
\text { (Dynamic) }\end{array}$ & Categorical & $\begin{array}{l}\text { Indonesia Population Census } \\
2010 \text { (BPS 2010) }\end{array}$ \\
\hline LZON & $\begin{array}{l}\text { Majority of legalized land use zone } \\
\text { (Static) }\end{array}$ & $\begin{array}{l}\text { Categorical } \\
\text { (HP=Production Forest; } \\
\text { APL=Non Forest Estate) }\end{array}$ & Forest Zone Map (MEF 2010) \\
\hline \multicolumn{4}{|c|}{ ACCESSIBILITY } \\
\hline ELEV & Mean elevation (Static) & Continuous (m a.s.l) & $\begin{array}{l}\text { SRTM 90m Digital Elevation } \\
\text { Database v4.1 (Jarvis et al. } \\
\text { 2008) }\end{array}$ \\
\hline$S L O P$ & Mean slope (Static) & Continuous (degree) & $\begin{array}{l}\text { SRTM 90m Digital Elevation } \\
\text { Database v4.1 (Jarvis et al. } \\
\text { 2008) }\end{array}$ \\
\hline CITY & $\begin{array}{l}\text { Mean distance to large cities or } \\
\text { arterial roads (Static) }\end{array}$ & Continuous (log(km)) & $\begin{array}{l}\text { Provincial map from Geospatial } \\
\text { Information Agency Indonesia } \\
\text { (BIG 2016) }\end{array}$ \\
\hline$P O P B$ & $\begin{array}{l}\text { Mean human population density per } \\
\mathrm{km}^{2} \text { prior to of oil palm development } \\
\text { (Dynamic) }\end{array}$ & Continuous (log(people)) & $\begin{array}{l}\text { Potensi Desa (PODES) (BPS } \\
\text { 2015) }\end{array}$ \\
\hline FORB & $\begin{array}{l}\text { \% natural forest cover a year prior to } \\
\text { oil-palm development (Dynamic) }\end{array}$ & $\begin{array}{l}\text { Categorical } \\
(1=0-25 \% ; 2=25-50 \% ; \\
3=50-75 \% ; 4=75-100 \%)\end{array}$ & $\begin{array}{l}\text { Global Forest Change dataset } \\
\text { (Hansen et al. 2013) and } \\
\text { Indonesia's primary and } \\
\text { secondary forest map (Margono } \\
\text { et al. 2014) }\end{array}$ \\
\hline \multicolumn{4}{|c|}{ AGRICULTURAL PRODUCTIVITY } \\
\hline$S D R Y$ & $\begin{array}{l}\text { Mean long-term monthly rainfall } \\
\text { during dry season (Static) }\end{array}$ & Continuous (mm) & $\begin{array}{l}\text { WorldClim (Fick \& Hijmans } \\
\text { 2017) }\end{array}$ \\
\hline SWET & $\begin{array}{l}\text { Mean long-term monthly rainfall } \\
\text { during wet season (Static) }\end{array}$ & Continuous (mm) & $\begin{array}{l}\text { WorldClim (Fick \& Hijmans } \\
\text { 2017) }\end{array}$ \\
\hline SOIL & Presence of peat soil (Static) & $\begin{array}{l}\text { Categorical } \\
\text { (1=Peat; } 0=\text { Mineral) }\end{array}$ & $\begin{array}{l}\text { Peat Hydrological Area Map } \\
\text { (MEF 2017) }\end{array}$ \\
\hline TRNS & $\begin{array}{l}\text { Mean distance to transmigration areas } \\
\text { prior to oil palm development } \\
\text { (Dynamic) }\end{array}$ & Continuous $(\log (\mathrm{km}))$ & Land Cover Map (MEF 2016) \\
\hline \multicolumn{4}{|c|}{ BASELINE VILLAGE SOCIOECONOMIC CONDITION } \\
\hline$\angle V H D$ & $\begin{array}{l}\text { Village primary livelihood at initial } \\
\text { stage of oil palm development } \\
\text { (Dynamic) }\end{array}$ & $\begin{array}{l}\text { Categorical } \\
\text { (SL=Subsistence livelihoods; } \\
\text { ML=Market-oriented } \\
\text { livelihoods) }\end{array}$ & $\begin{array}{l}\text { Potensi Desa (PODES) (BPS } \\
\text { 2015) }\end{array}$ \\
\hline$W L B N_{k}$ & $\begin{array}{l}\text { Baseline well-being indicator } k \text { (Table } \\
\text { 1) at initial stage of oil palm } \\
\text { development (Dynamic) }\end{array}$ & $\begin{array}{l}\text { Either continuous or } \\
\text { categorical }\end{array}$ & $\begin{array}{l}\text { Potensi Desa (PODES) (BPS } \\
\text { 2015) }\end{array}$ \\
\hline VILA & Extent of village (Static) & Continuous $\left(\mathrm{km}^{2}\right)$ & $\begin{array}{l}\text { Potensi Desa (PODES) (BPS } \\
\text { 2015) }\end{array}$ \\
\hline \multicolumn{4}{|c|}{ RECENT CLIMATE } \\
\hline$T D R Y$ & $\begin{array}{l}\text { Mean monthly rainfall during the dry } \\
\text { season over the time frame assessed } \\
\text { (Dynamic) }\end{array}$ & Continuous (mm) & $\begin{array}{l}\text { TRMM Multi-Satellite } \\
\text { Precipitation Analysis (TMPA) v. } \\
7 \text { (Huffman et al. 2007) }\end{array}$ \\
\hline TWET & $\begin{array}{l}\text { Mean monthly rainfall during the wet } \\
\text { season over the time frame assessed } \\
\text { (Dynamic) }\end{array}$ & Continuous (mm) & $\begin{array}{l}\text { TRMM Multi-Satellite } \\
\text { Precipitation Analysis (TMPA) v. } \\
7 \text { (Huffman et al. 2007) }\end{array}$ \\
\hline
\end{tabular}

$\S$ Static: vary spatially but are fixed through time, and Dynamic: vary both spatially and temporally. 


\section{Materials and Methods}

\subsection{Study area}

Our study covered Kalimantan $\left(540,000 \mathrm{~km}^{2}\right)$, the Indonesian portion of the island of Borneo, comprising five provinces and 6,600 villages in 2010 (BPS 2010). Kalimantan's interior is largely hilly and mountainous, but extensive lowlands and swamps occur along the coasts. A large part of the region is drained by navigable rivers. In 2015, the population of Kalimantan was estimated as 15 million (BPS 2015), with many mainly residing along the coastline (Fig. 1A). Communities are comprised of three broad ethnic groups: the indigenous Dayak predominantly residing in the interior regions, the indigenous Melayu (of which the majority are Muslim) occupying mainly the coastal regions, and recent migrants from the neighbouring islands of Java, Madura and Bali (arriving mainly as part of the government-supported transmigration programs since the 1960s) (Fig. 1B). Village economies in Kalimantan have traditionally been based on subsistence agriculture (i.e. swidden farming and seasonal inland fishing) and forestry, but plantation agriculture (both polyculture and monoculture) has become an increasingly vital sector in recent decades (Fig. 1C).

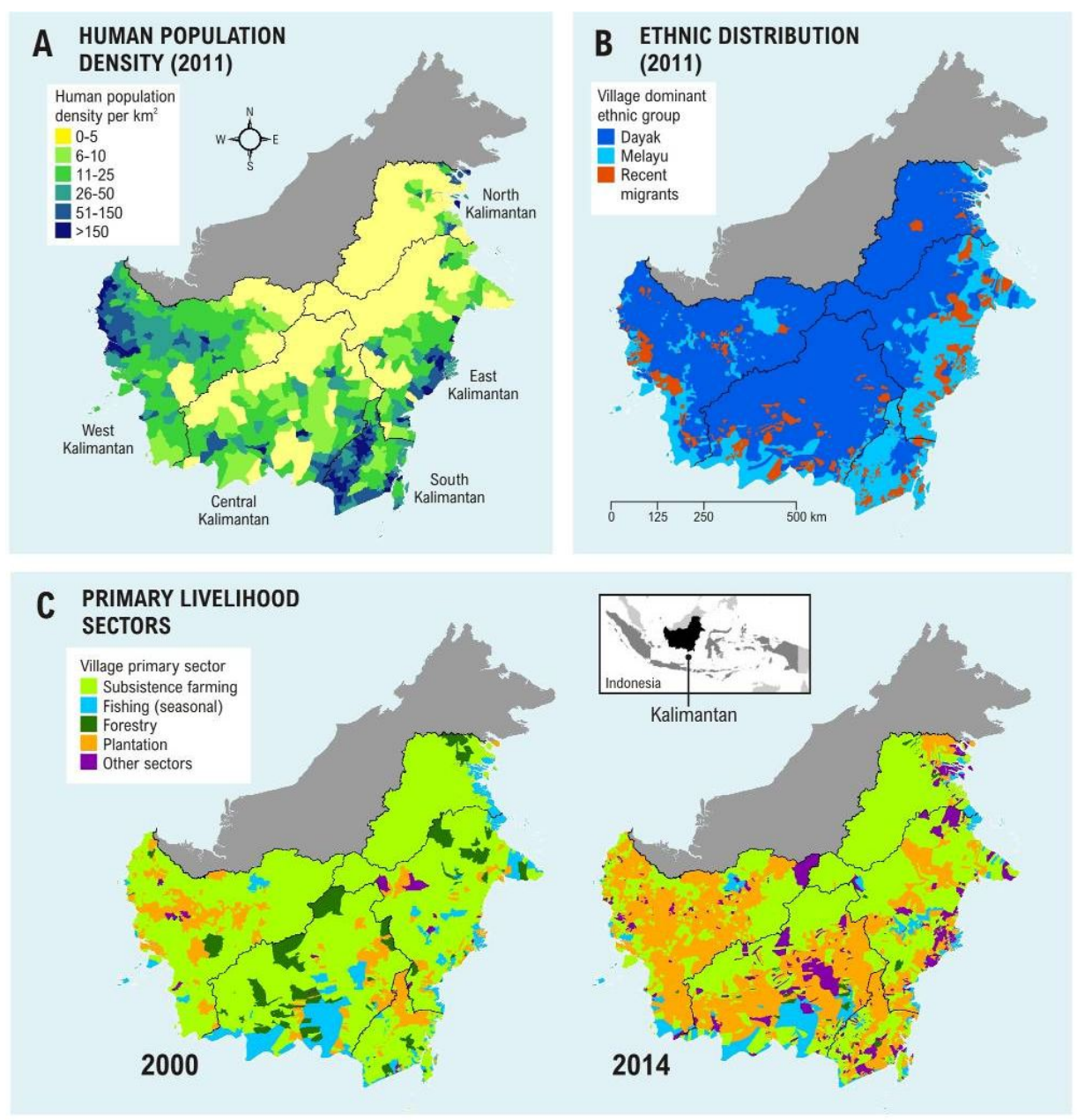

Fig. 1. (A) Human population density (per $\mathrm{km}^{2}$ ), and (B) village dominant ethnic group, in Kalimantan based on PODES 2011 (data closely reflect the results of 2010 national census). (C) Change in village primary livelihood sectors between 2000 and 2014, which includes subsistence farming, seasonal inland fishing, forestry, plantation (polyculture or monoculture), and other sectors (including horticulture, aquaculture, agricultural services, and non-agricultural sectors). Black lines in the maps indicate provincial boundaries. 


\subsection{Oil palm plantations}

We used spatial data on the boundaries of planted oil palm plantations every five years between 1995 and 2015 provided by Gaveau et al. (2016a). These data comprise estates located within the boundaries of oil palm concessions, including large-scale industrial plantations, smallholders under the Perkebunan Inti Rakyat (PIR) or Nucleus Estate Smallholder schemes in transmigration areas (McCarthy et al. 2012), and a smaller extent of independent smallholders (outside oil palm concessions) (Fig. A1a). It is worth noting that the proportion of industrial plantation estates in Kalimantan is much higher than in neighbouring Sumatra (64\% of all plantations in Kalimantan, $33 \%$ in Sumatra, in 2015, Fig. A1). Oil palm developments at different spatial scales (smallholder to large industrial scale) usually coincide spatially due to their reliance on access to palm oil mills and related services (Klasen at al. 2016), hence our analysis reflects more broadly the effects of all oil palm developments. In addition, the proportion of oil palm plantations that have been certified through internationally recognized certification bodies, such as the Roundtable on Sustainable Palm Oil (RSPO), between 2000 and 2015 is relatively small (around 12\% by 2015) (Fig. A1). Kalimantan's oil palm plantations have expanded rapidly over the last decades, covering a total area of $13,000 \mathrm{~km}^{2}$ (in 1073 villages) in 2000, tripling to 40,000 km² (in 1980 villages) in 2015 (Fig. A2).

\subsection{Indicators of well-being}

Village-level data, Potensi Desa (PODES), collected by the Indonesian Bureau of Statistics (BPS) roughly every three years between 2000 and 2014 (BPS 2015), were used as proxy indicators of five dimensions of village well-being (Table 1, with associated questionnaires provided in Table B2). The data are the most comprehensive information on land use, population demographics, and village infrastructure available in Indonesia, and have been used extensively to inform government policy, as well as socioeconomic studies (Table B3). The choice of indicators and directionality of the effects on well-being listed in Table 1 correspond to existing methodologies used to assess poverty and livelihoods, such as the Multidimensional Poverty Index (MPI, Alkire et al. 2014), the Sustainable Livelihood Approach (SLA, Scoones 1998), and the Nested Spheres of Poverty (NESP, Gönner et al. 2007) (Fig. A4).

PODES data represent the overall socioeconomic conditions in a village, and thus do not capture the variation and disparity in socioeconomic indicators among different sub-villages (dusun) nor households. Rather, the data provide a useful way to compare village administrative units over large spatial extents. PODES data are collected from the village head offices by BPS representatives, thus the reliability of data may vary across different villages and there is potential for bias, e.g. under-or overreporting. However, should this random bias propagate sufficiently, we expect that the error would be inflated and override the true oil palm effect, and thus the estimated effect of oil palm would appear negligible, as opposed to changing the directionality of the effect.

\subsection{Analysis methodology}

\subsubsection{Unit of analysis}

We used the village administrative unit as the spatial unit of analysis, which was defined according to the Bureau of Statistics Indonesia in 2010 census (BPS 2010). We assessed the impact of oil palm on the change in village well-being following 2-3, 6-8, and 11-14 years of plantation age, which allows understanding of the complex temporal dynamics of oil palm impacts across different indicators of wellbeing in different contexts. To do so, we compared the change in well-being indicators between paired PODES censuses (Table B4). 
Oil palm usually takes 3-4 years to mature to produce commercially viable yields (Basiron 2007; Lee et al. 2014), hence profits from plantations are usually realized after at least 3 years. Smallholders under the Nucleus Estate Smallholder schemes (who are normally tied to transmigration areas) typically use these initial profits to gradually pay back investment from their nucleus company, and are only able to pay off their debt around 6 years after planting (Feintrenie et al. 2010). For independent smallholders the realization of socioeconomic benefits would depend on land ownership and starting capital (Lee et al. 204; Euler et al. 2016). Regardless of the types of oil palm plantation holders, we expect the economic benefits to be realized after the first harvesting cycle between 3 and 8 years.

Changes in indicators of social well-being, such as the frequency of conflicts, may occur either during the oil palm development stage or several years after planting. Land grabbing disputes are expected to manifest early in the oil palm development stage, whereas conflicts due to unfulfilled promised benefits and compensation are expected to occur several years later (Wakker et al. 2004; Colchester et al. 2006; Rist et al. 2010). The prevalence of agricultural wage labourers is expected to increase dramatically during the oil palm development stage, especially when a plantation reaches its full production level (Potter 2012). Changes in indicators of environmental well-being, such as water pollution, are likely to occur after the oil palm infrastructure, including mills, are established and palm oil production begins in earnest, although these impacts could take some years before they are noted (Comte et al. 2012; Obidzinski et al. 2012).

As the unit receiving treatment, we used villages where oil palm plantations were detected as the primary land use over the full analysis periods, but not within the prior five years. As the unit for control, we used villages where oil palm plantations were not detected as the primary land use over the range of analysis period, nor in the prior five years. For example, to assess the effect of oil palm on the change in village well-being between the 2003 and 2011 PODES censuses (eight years of plantation age), the unit receiving treatment were villages where oil palm plantations were detected within the village boundaries in 2005 and 2010, but not in 2000, and the control unit were villages where oil palm plantations were not detected within the village boundaries in 2000, 2005 and 2010. Therefore, the number of villages in the treated and control unit vary depending on the time frame of analysis, as shown in Table B4.

\subsubsection{Confounding variables}

We controlled for potentially confounding variables in the assessment of oil palm impact in terms of both selection of villages for treatment and the outcome being measured (Table 2). To achieve this we included variables representing: (a) socio-political factors, (b) accessibility, (c) agricultural productivity, (d) baseline village socioeconomic conditions, and (e) recent climate.

We used the regency administration boundaries (kabupaten) (variable $K A B U$ in Table 2) and land use regulation (LZON) as proxies for socio-political factors. Decentralization of government functions to regency levels has been identified as a key driver of deforestation, land degradation and conversion of forest to agriculture in Indonesia (Resosudarmo 2004; Moeliono \& Limberg 2012). Oil palm plantations in Kalimantan are typically developed either outside the Forest Estate Zone, Area Penggunaan Lain (APL), or inside the Forest Estate Zone in Production Forest, Hutan Produksi (HP).

Average elevation (ELEV) and slope (SLOP), proximity to large cities or arterial roads (CITY), human population density $(P O P B)$, and forest cover (FORB) were used as proxies for accessibility. Oil palm is typically developed in villages with particular topographical characteristics, e.g. flat or lightly undulating land with good access to water. Villages located within proximity to major roads and towns tend to be converted first to agriculture because the land is more accessible (Kinnaird et al. 2003; Linkie et al. 2004). Villages within proximity to major roads and towns, higher human population density, and relatively low forest cover are also recognized to be associated with communities with higher baseline cash income and economic welfare (Belcher et al. 2015). 
We used long-term seasonal rainfall patterns (SDRY and SWET), presence of peat soil (PEAT), and distance to transmigration areas (TRNS) as proxies for agricultural productivity. The amount of rainfall during the dry and wet seasons is the most important factor affecting agricultural productivity in Indonesia (Oldeman \& Frere 1982; Santika et al. 2017a). Soil type, i.e. mineral or peat soil, is also an important factor driving forest conversion to agriculture (Carlson et al. 2013). The increase in agriculture area in Indonesia had been partly attributed to an increase in transmigration sites and expansion of oil palm plantations (Dennis \& Colfer 2006).

Village primary livelihoods ( $L V H D)$ and well-being conditions (WLBN) at the initial stage of oil palm developments, and the extent of village (VILA) were used as proxies for baseline village socioeconomic conditions. These variables provided a baseline to control for conditions that may have biased impact estimates. We used the monthly average of rainfall during the dry and wet seasons over a given time frame of analysis (TDRY and TWET) as proxies for recent climate conditions (Santika et al. 2017b). These variables are important for assessing the association between oil palm and natural hazards, such as water and air pollution, and floods and landslides (Tosca et al. 2011; Merz et al. 2014).

\subsubsection{Matching method}

We employed a matching method (Dehejia \& Wahba 2002) to select a set of control villages in which oil palm plantations had not been developed and that exhibited the same baseline characteristics as villages where plantations had been established. The matching method was performed based on nearestneighbour matching of propensity scores based on all variables described in Table 2 and exact matching of the categorical baseline variables (i.e. KABU, LZON, SOIL, FORB, LVHD, and WLBN). We used matching algorithms implemented in the R-package Matching (Sekhon 2015). We used a non-parametric generalized boosted regression model (Friedman 2001) for binary outcomes implemented in the Rpackage gbm (Ridgeway et al. 2015) to generate the propensity scores. The model allows flexibility in fitting non-linear surfaces for predicting treatment assignment and can incorporate a large number of covariates without negatively affecting model prediction. In various applications, this modelling approach has been shown to outperform other methods that require model selection, specification of model functional form, and are lacking flexibility, such as the commonly used generalized linear model (Lee et al. 2010). We used a 0.25 calliper width of the propensity scores' standard deviations in the nearest neighbour approach, as this width was previously shown to be optimal (Austin 2011). The matching method was applied separately for each of the 17 indicators of well-being and for each time period analysis. We observed substantial improvement in the extent of overlapping areas of all continuous variables between villages with and without plantation development in the matched dataset compared to the original (unmatched) dataset (Fig. A5).

\subsubsection{Assessing impact of oil palm plantations}

The impact of oil palm on human-well-being was estimated by comparing the change in well-being indicator in villages with oil palm plantations with the change in control villages without plantations. A village $i$ within an oil palm plantation is considered to be effective at alleviating a single indicator of wellbeing $k$ over time period $t$ if the difference between the change in the value of the indicator in the treated village $\left(O_{i, t, k}\right)$ and the rate in the control village $\left(C_{i, t, k}\right)$, i.e. $A_{i, t, k}$, where $A_{i, t, k}=w_{k} \times\left(O_{i, t, k}-C_{i, t, k}\right)$, is positive. The value of $w_{k}$ represents the directional effect of the change in indicator $k$ that defines improvement in well-being (Table 1), i.e. $w_{k}=1$ if positive change (or an increase) in indicator $k$ represents improvement in well-being (e.g. proportion of household with electricity) and $w_{k}=-1$ if negative change (or a reduction) in indicator $k$ represents improvement in well-being (e.g. malnutrition prevalence, conflict frequencies). The estimated impact of oil palm based on indicator $k$ over time period $t$, i.e. $\bar{A}_{t, k}$, was then obtained by fitting an ordinary linear regression model with $A_{i, t, k}$ as a response and a binary variable representing the treated and the control villages and all variables described in Table 2 as predictors. We then normalized the estimated treatment effects for each indicator of well-being. To obtain the overall efficacy of oil palm in improving each aspect of well-being $m$ for plantation age $h$, i.e. $\breve{A}_{m, h}$, we averaged $\bar{A}_{t, k}$ across all indicators 
$k$ belonging to the same group of well-being aspect $m$ (Table 1 ) and across time period $t$ belonging to the same group of plantation age $h$ (Table B4).

While the value of $\breve{A}_{m, h}$ is an informative measure of the overall impact of oil palm in improving each aspect of well-being for a given plantation age, it is also of interest to understand how efficacy varies spatially. We conducted a systematic review on past, local-level evaluations of oil palm impacts (Table B1), and based on this review we stipulated that baseline community livelihoods in the earliest stage of oil palm development, particularly between subsistence-based livelihoods and market-oriented livelihoods, play an important role in altering the direction and relative magnitude of oil palm impact on well-being. An overall positive association between oil palm plantations and socioeconomic well-being was found in villages where the majority of communities rely on market oriented livelihoods ( $92 \%$ of the studies we reviewed indicate a positive association). In contrast, an overall negative association was found in villages where the majority of communities rely on subsistence livelihoods $(60 \%$ of the studies we reviewed indicate a negative association). For social and environmental well-being, none of the studies we evaluated reported positive impacts of oil palm.

To assess the robustness of the matching method against the possible presence of an unobserved confounder, we applied a sensitivity analysis based on the principle of randomization inference (Rosenbaum 2005) implemented in R-package rbounds (Keele 2014). This approach relies on the sensitivity parameter $\Gamma$ that measures the degree of departure from random assignment of the treatment, in this case, oil palm plantation villages. A threshold value of $\Gamma$, namely $\Gamma_{c}$, was calculated at the point at which hidden bias would eliminate the effect of oil palm plantations. A study is considered sensitive to hidden bias, i.e. the effect of oil palm plantation development likely can be explained by an unobserved covariate, if $\Gamma_{c}<1$, and a study is considered robust if the value of $\Gamma_{c}$ is large. The sensitivity analysis indicated that our estimate on the impact of oil palm plantation on all the well-being indicators for each time period based on matching was robust to the possible presence of an unobserved confounder, as indicated by relatively large values of the sensitivity parameter threshold $\Gamma_{c}\left(\Gamma_{c} \geq 1.72\right)$ (Table B5).

\section{Results}

\subsection{Market economy characteristics of the baseline livelihoods}

Living conditions (electricity, adequate sanitation, non-wood cooking fuel), access to infrastructure (schools and healthcare facilities), and various credit schemes were better in villages where marketoriented livelihoods dominated than in villages where most communities depended on subsistence livelihoods (Fig. A6a-C). The biophysical features of these villages, i.e. proximity to major cities and roads, may have contributed to creating such conditions (Fig. A7). In villages where subsistence-based livelihoods dominated, basic infrastructure was generally lacking due to isolation, and households with poor living conditions were common (Fig. A6a). Despite lacking material wealth, however, malnutrition rates among infants were lower in subsistence-based livelihood villages (Fig. A6a), which could reflect access to a greater variety of food sources (fruits, vegetables, and medicinal plants) due to high levels of food selfsufficiency through farming and forest product collection (Budiharta et al. 2016; Ickowitz et al. 2016). Moreover, the occurrence of cooperative schemes and micro enterprises ( $<20$ employees, mainly in forestry related products, such as rattan) were higher overall (Fig. A6c). Nearly $60 \%$ of the new oil palm plantations developed between 2000 and 2015 in Kalimantan were situated in villages where the majority of communities had relied on subsistence-based livelihoods (Fig. A3b). 


\subsection{Overall effect of oil palm on village well-being}

We found an overall increase in basic, physical and financial indicators of well-being between 2000 and 2014 , both in villages with oil palm plantation developments and those without such developments across Kalimantan between 2000 and 2014 (Fig. 2A-C). Conversely, there was an overall decline in social and environmental measures of well-being (Fig. 2D-E). On average the improvements in basic, physical and financial well-being occurred more slowly in villages with oil palm plantations compared to those without, for villages of similar biophysical features and baseline community socioeconomic conditions (Fig. 2F-H). Moreover, the decline in social and environmental well-being had occurred significantly faster overall in villages with oil palm plantations compared to villages without plantations (Fig. 2I-J).

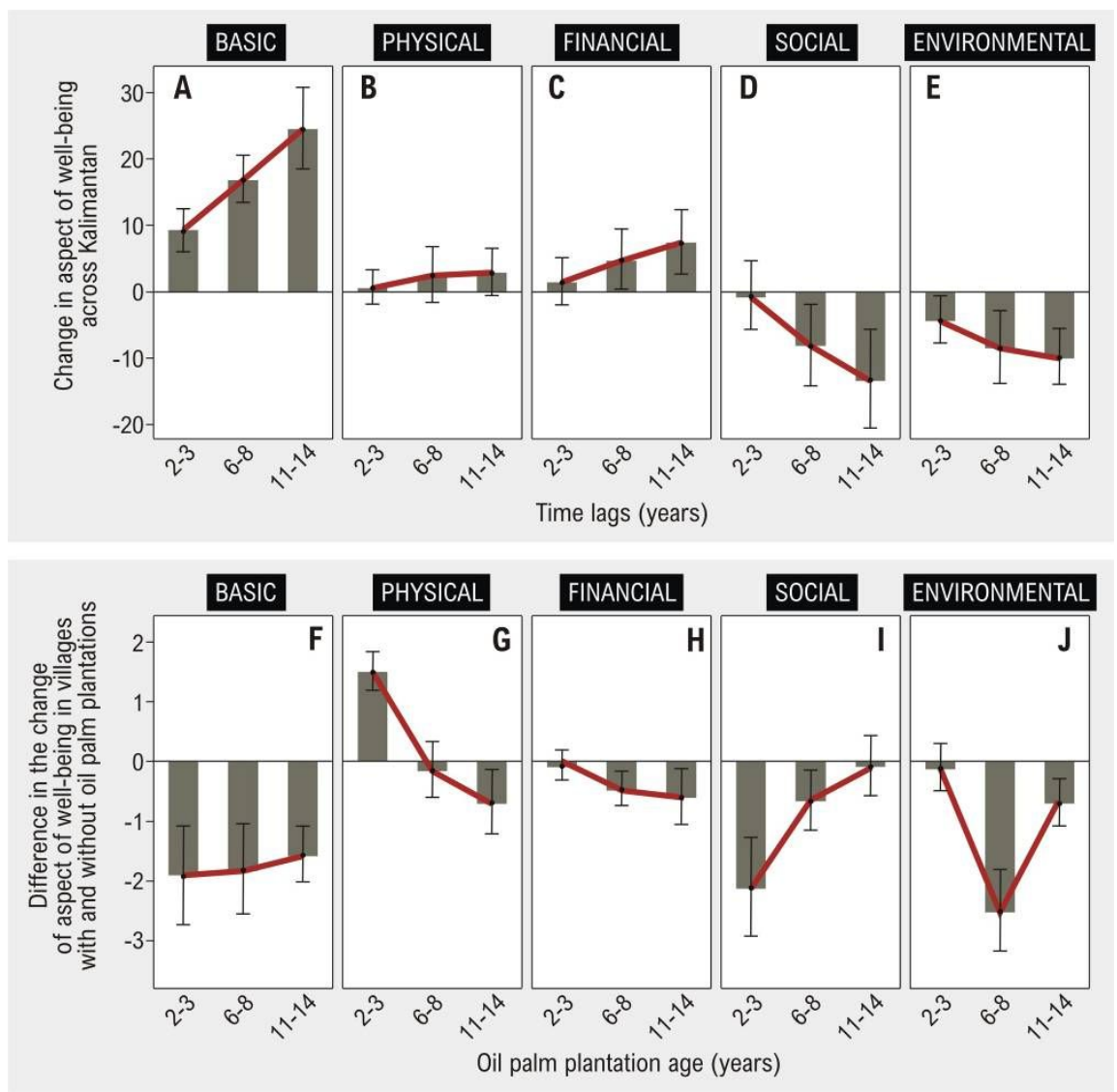

Fig. 2. (A-E) Mean rate of change in human-well-being across Kalimantan villages for varying time lags, which correspond to plantation ages since establishment. (F-J) Difference in the mean rate of change of well-being over the same time lags in villages with and without oil palm. Large negative values indicate higher reduction of well-being relative to the counterfactual. Aspects of well-being assessed include: $(A, F)$ basic well-being (living condition), $(B, G)$ physical well-being (infrastructure), $(C, H)$ financial well-being (income support), (D,I) social well-being (security and social equity), and $(E, J)$ environmental well-being (natural hazard prevention). Error bars represent $95 \%$ confidence intervals.

\subsection{Benefits vary with baseline conditions}

Despite the overall negative association between of oil palm and all aspects of human-well-being (Fig. 2F-J), these associations varied across different baseline community livelihoods at the initial stage of plantation development (Fig. 3). While the association between oil palm development and basic, physical, and financial well-being appeared to be negative overall in villages where communities had relied 
formerly on subsistence-based livelihoods, the association was positive overall in villages where communities had relied on market-oriented livelihoods (Fig. 3A-C). However, the negative association between the industry and social and environmental well-being appeared to be more severe in villages that formerly relied on market-oriented livelihoods compared to villages with livelihoods that were formerly subsistence-based (Fig. 3D-E).

In villages that formerly relied on market-oriented livelihoods water and air pollution were reported to be more severe compared to villages that were mostly subsistence-based (Fig. 4E). This could reflect substantially higher agriculture intensification and the occurrence of more oil palm mills in the former (Fig. A7f). An increase in frequency of floods and landslides was reported to be greater in oil palm villages where communities formerly depended on subsistence-based livelihoods (Fig. 4E). The rate of forest conversion ( $>60 \%$ forest cover) within five years prior to oil palm plantation developments was comparatively similar to villages that formerly relied on market-oriented livelihoods (Fig. A8). However, most of the near-intact forest being cleared for plantations in former subsistence-based livelihoods villages was located at relatively high altitude and had received considerable amount of rain during the wet season over the last decades (Fig. A7a-b).

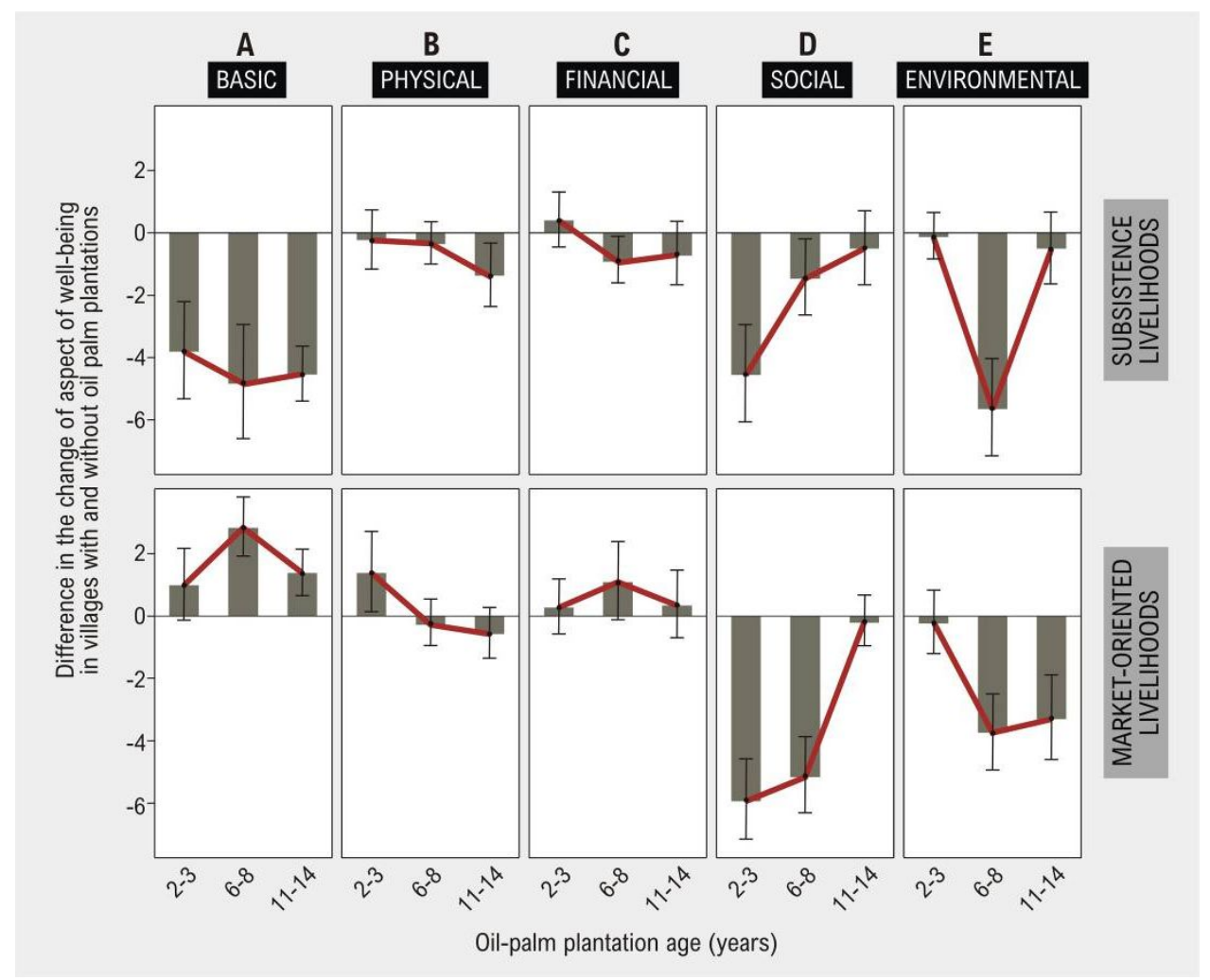

Fig. 3. Difference in the mean rate of change of aspects of well-being over varying oil palm plantation ages in years, in villages with and without oil palm, where most communities formerly depended on: subsistencebased livelihoods or market-oriented livelihoods. Large negative values indicate a greater decline in well-being relative to the counterfactual. Aspects of well-being include: (A) basic well-being (living condition), (B) physical well-being (infrastructure), (C) financial well-being (income support), (D) social well-being (security and social equity), and (E) environmental well-being (natural hazard prevention). Error bars represent $95 \%$ confidence intervals. 


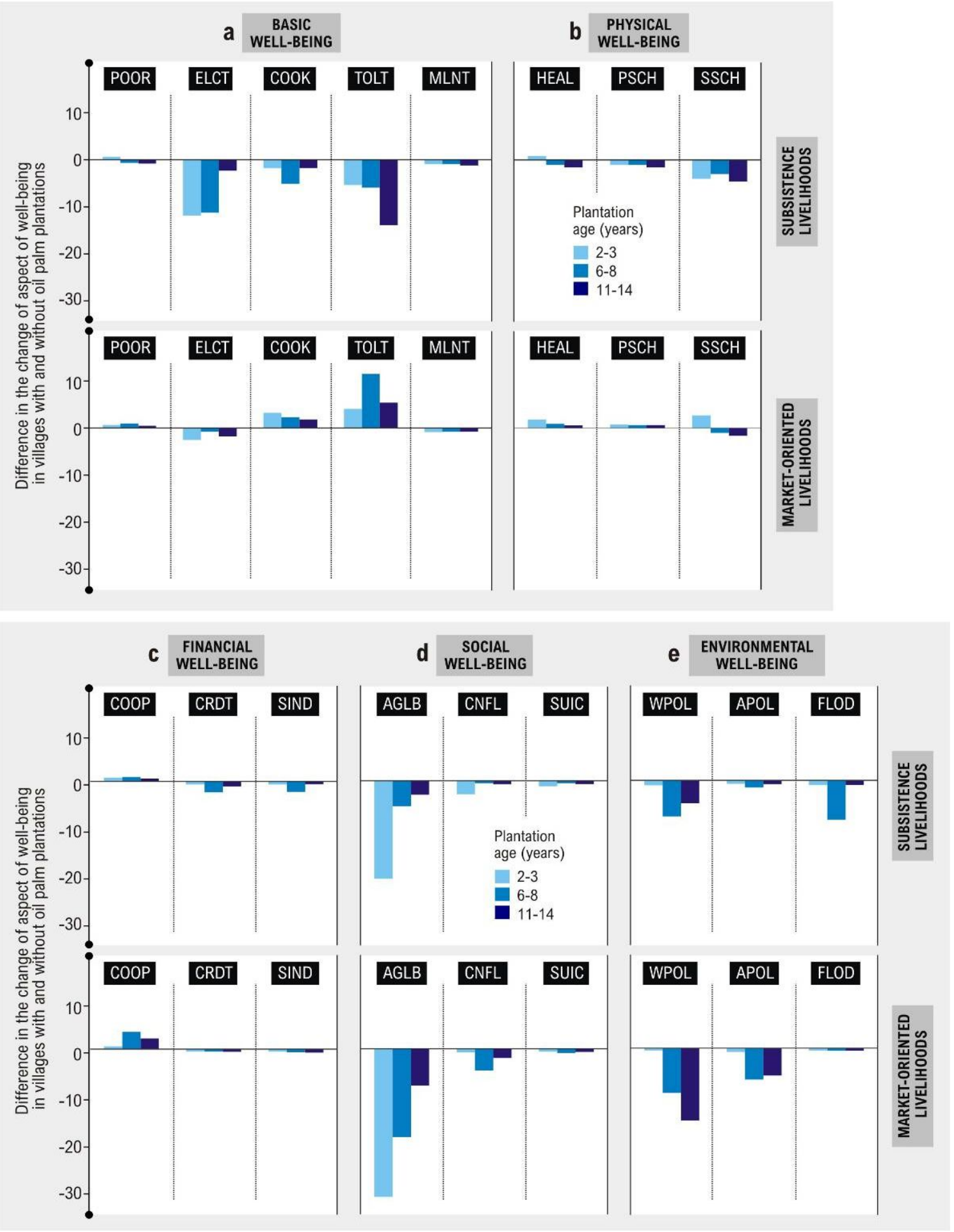

Fig. 4. Difference in the mean rate of change of aspects of well-being over varying oil palm plantation ages (in years) between villages with and without oil palm, where most communities formerly depended on subsistence-based livelihoods or market-oriented livelihoods. Large negative value indicates higher reduction of aspect of well-being relative to the counterfactual. Aspects of well-being include: (A) basic well-being (living condition), (B) physical well-being (infrastructure), (C) financial well-being (income support), (D) social wellbeing (security and social equity), and (E) environmental well-being (natural hazard prevention). Detail explanation for each variable is provided in Table 1. 


\subsection{Benefits vary through time}

\subsubsection{Socioeconomic effect}

In villages that had an existing market economy we observed that basic well-being indicators, such as adequate sanitation and energy for cooking, improved 6-8 years after a plantation had been established (Fig. 4A). Physical well-being indicators such as access to healthcare facilities and secondary schools primarily improved in the early stages (i.e. 2-3 years) of oil palm plantation development (Fig. 4B). Financial well-being improved mainly through increased access to credit schemes after 6-8 years (Fig. 4C).

On the other hand, for oil palm established in villages where most communities had relied on subsistence-based livelihoods, we observed the opposite trends on socioeconomic aspects of well-being. Basic well-being indicators such as access to electricity, adequate sanitation and energy for cooking were markedly reduced since the early stages (i.e. 2-3 years) until 11-14 years of oil palm plantation development compared to the control villages (Fig. 4A). Physical well-being indicators, in particular access to secondary schools, were also reduced (Fig. 4B). Reduced basic and physical well-being relative to the controls likely occurred due to a combination of the remoteness of villages (Fig. A7c) and the influx of workers from outside the region. An increase in wage labourers in these villages was substantially higher compared to the controls in the first 2-3 years of plantation development (Fig. 4D), and the ethnic diversity of communities also increased after plantations were established (Fig. A9b). Labour influx in some villages may be related to the existing low population density of these villages (Fig. A7d).

In villages where most communities had relied on subsistence-based livelihoods, financial wellbeing indicators (e.g. access to cooperative schemes, number of small enterprises) reduced relative to the controls after 6-8 years of plantation development (Fig. 4C). This could reflect the impact of increased specialisation towards cash cropping (Cramb et al. 2009; Kremen et al. 2012) and increased scarcity of forest products, such as rattan (Meijaard et al. 2014).

\subsubsection{Environmental impacts}

Water and air pollution in oil palm landscapes is sometime associated with the production of palm oil mill effluent (POME) in the oil extraction process after harvesting (Singh et al. 2010). This could explain why water and air pollution was often reported in the 6-8 years after plantation establishment (Fig. 4E), around the period when fruit yields have become substantial (Carter et al. 2007). Excessive applications of pesticides and fertiliser could also contribute to water pollution (Meijerink et al. 2008; Comte et al. 2012). It has been estimated that for every tonne of crude palm oil produced, about 2.5 tonnes of liquid waste is generated (Ahmad et al. 2003), although companies vary on how this waste is treated.

\subsection{Interacting and possible spillover effects}

The influx of workers in remote villages that lack infrastructure facilities (Fig. A6a-b) could be associated with the reported reduction in electricity provision, clean sanitation, energy for cooking, and secondary schools, which were all substantially greater in these villages compared to the counterfactual (Fig. 4A-B). This does not necessarily mean that such facilities are reduced in villages with oil palm development, but it is rather caused by reduced proportion on the provision of such facilities relative to village population as the population increased. An increase in waged labourers from outside the region not only occurs in remote villages where most communities had relied on subsistence-based livelihoods, but also in semirural villages where communities were formerly dependent on market-oriented livelihoods. In the latter, the increase in waged labourers was substantially higher relative to the controls up to 6-8 years of plantation being established (Fig. 4D). This could reflect higher pressure to intensify agricultural production and labour requirements, both for plantations and oil palm mills that largely occur in semirural villages (Fig. A7f). 
Conflicts have occurred more frequently in villages where communities formerly relied on marketoriented livelihoods, particularly after 6-8 years of plantation age (Fig. 4D). In these villages it is possible that these conflicts are triggered by communities' discontent over insufficient company benefit sharing to local communities (Sheil et al. 2009; Abram et al. 2017) after initiation of harvesting at around four years (Carter et al. 2007), as well as a signal of rising social inequalities and disparities (Euler et al. 2017). On the other hand, in villages formerly relying on subsistence-based livelihoods, conflicts mostly occurred at the start-up phase of plantations (i.e. 2-3 years). In former subsistence-based villages, indigenous communities dominate (Fig. A9a). In these villages, the conflicts could be a result of the loss of indigenous land and perceived lack of land compensation at the beginning of plantation development (2-3 years), due to a weak land tenure system (Colchester et al. 2006).

\section{Discussion}

There is a widespread belief that oil palm development results in increased socioeconomic wellbeing. Yet, in Kalimantan, we found that the socioeconomic effects of the industry were not always equal across villages, and depended on the biophysical characteristics and baseline socioeconomic conditions of communities prior to oil palm development. In villages where communities had mostly relied on marketoriented livelihoods, oil palm development was associated with increased basic, physical and financial well-being. However, in remote forested villages where communities had often relied on subsistencebased livelihoods, a substantial reduction in basic, physical and financial well-being was observed, along with reduced social and environmental well-being. This could reflect harmful implications of rushed development in remote areas where the government's regulatory powers and monitoring capacity are limited (Zoomers et al. 2017). Two-thirds of the new oil palm plantations developed between 2000 and 2015 in Kalimantan were situated in villages where the majority of communities had relied on subsistencebased livelihoods. Further expansion of oil palm in remote forested landscapes, such as in Kalimantan and Papua, should therefore be considered more carefully. While poverty can be caused by isolation, abrupt contact with a market economy can lead to exacerbation of poverty and displacement of communities who are not well integrated in the market system. Alternative policies that could facilitate local communities in remote areas to thrive and prosper given the right skills, strengths, and social context should be sought (Ruiz-Pérez et al. 2004; Shackleton et al. 2011).

For oil palm industries that have been developed, regardless of baseline village livelihood sector, our findings show that unsustainable livelihoods, increased socioeconomic disparity, and environmental issues remain major challenges. Local communities are burdened with the socioeconomic and environmental costs of poorly planned and implemented development, while a small number of rural and urban elites may take the largest share of economic benefits (Sheil et al. 2009). Taxation of oil palm with direct production bonuses accruing at regency and district levels could ensure that the economic benefits of industrial oil palm directly compensate local development costs (McCarthy et al. 2012; Falconer et al. 2015). However, to achieve this would require several vital adjustments in terms of (a) fiscal policy on collection and redistribution of revenues, (b) monitoring and regulation of tax compliance, and (c) data sharing and transparencies among different key government ministries involved in the oil palm sector (i.e. Ministry of Environment and Forestry; Ministry of Agriculture; Ministry of Villages, Disadvantaged Regions and Transmigration; Ministry of Finance; and Ministry of Agrarian Affairs and Spatial Planning). These issues are inextricably and causally intertwined, and they ought to be addressed in concert.

The current fiscal policy in Indonesia highlights relatively low levels of tax collection from the oil palm industry and redistribution of revenues to local governments, with only an estimated $14 \%$ of palm oil tax revenues being redistributed to local governments (Falconer et al. 2015). Corruption and lack of tax compliance are recognized as key reasons for low levels of tax collection, and are considered to be the biggest issues tainting the reputations of many oil palm companies in Indonesia (Falconer et al. 2015; CNN Indonesia 2017; Mongabay 2018a). In the provinces of West Kalimantan and Riau alone, only $10 \%$ and 
$30 \%$ oil palm plantation companies have complied with their tax obligations, respectively (Tempo 2016; Times Indonesia 2018). Indonesia's Corruption Eradication Commission, known as KPK, has recently been called upon to intervene in the country's palm oil sector with the hope of rectifying this problem (Tempo 2017c; Mongabay 2018a). However, the work of the KPK also faces tremendous challenges given uncertainty in land ownership and permits, and lack of data sharing and transparencies among different government ministries, as reflected by the slow progress in the implementation of One Map Policy or Kebijakan Satu Peta (KSP) that attempts to bring together data from different government departments in a single spatial platform (Kompas 2018). The KSP data portal was eventually launched by the Indonesian President in December 2018, and this is a substantial achievement. However, the accessibility of the data is currently restricted only to the President and Vice President, government ministries, and local government heads, i.e. Governors and Bupati (Head of Regency) (Presidential Instruction No. 20/2018). Excluding non-governmental organizations and the general public from accessing these data fundamentally limits the utility and the main goal of the KSP in providing transparency and inclusiveness (Mongabay 2018b). It is also recognizable that analysing multifaceted geospatial data would require adequate skills in data processing, modelling, and analysis, and importantly collaborative efforts across different disciplines and levels of society to provide accurate interpretation in different contexts, in which the public could greatly assist (Mongabay 2018b). Mechanisms for including public participation in analysing the data are required for the effectiveness of the KSP, not only to resolve conflicts related to overlapping land permits, but also to provide foundations for good governance and planning for healthy and sustainable developments that ultimately benefit rural people in the long run.

While our study provides an understanding of the impact of oil palm development in general across different types of plantations, it is worth mentioning that there are currently a few mechanisms that attempt to improve the performance of oil palm plantations to deliver socioeconomic benefits to villages. Certification schemes, such as the Roundtable on Sustainable Palm Oil (RSPO), could help considerably, although by 2015 , only $12 \%$ of the oil palm plantations in Kalimantan that had been certified (Fig. 1A). Although many of the earlier plantations in Kalimantan and Sumatra contained little forest when they were RSPO certified, Carlson et al. (2018) demonstrated that most of these plantations reduced deforestation rates. On the other hand, the impact of this scheme in reducing fire occurrences (Cattau et al. 2016; Noojipady et al. 2017; Carlson et al. 2018) and delivering socioeconomic benefits to village communities are questionable (Morgans et al. 2018). Further scrutiny of the RSPO-certified plantation estate using our analytical framework could help address this knowledge gap.

While the premise regarding variation in the impact of large-scale agriculture, land reform, and development in general in different locations has been reported in numerous studies (e.g. Mertz et al. 2009; Shete \& Rutten 2015), evidence for the heterogeneity of the impact on well-being was lacking for the oil palm. Lack of understanding and evidence about the conspicuous difference between the impact of oil palm on market-oriented livelihoods and the impact on subsistence-based livelihoods is (and is used as) a basis of constant debate in the Indonesian politics on development objectives, particularly between the Ministry of Environment and Forestry (who effectively has jurisdiction in the majority of forest area and is responsible for the welfare of nearby communities who largely depend on subsistence-based agriculture, including farming, fishing and gathering of non-timber forest products), the Ministry of Agriculture (who is responsible for commercialized agriculture sector and welfare of the peasants), and the Ministry of Villages, Disadvantaged Regions and Transmigration (who is responsible for advancing developments in the outer islands of Java and transmigration programs) (Mongabay 2016; Tempo 2017a, b). For the local government at Kabupaten or Regency level, direction towards supporting versus resisting oil palm is likely to be informed by the vision of most communities: either to pursue socioeconomic growth or to maintain socioecological capital. Regencies where the majority of communities depend highly on forest environmental income (which tend to be of indigenous background with stronger ties to ancestral land) may place higher importance on maintaining socioecological values (Potter 2009; Sirait 2009). Acknowledging that the impacts of oil palm developments can be fundamentally different across different baseline village livelihood systems should inform fruitful multi-level and cross-sectoral government discussions on the long-term risks and benefits of oil palm plantation on the well-being of local communities. 


\section{References}

Abram, N.K., Meijaard, E., Wilson, K.A., Davis, J.T., Wells, J.A. et al. (2017) Oil palm-community conflict mapping in Indonesia: A case for better community liaison in planning for development initiatives. Applied Geography 78, 33-44.

Ahmad, A.L., Ismail, S. \& Bhatia, S. (2003) Water recycling from palm oil mill effluent (POME) using membrane technology. Desalination 157, 87-95.

Alkire, S., Chatterjee, M., Conconi, A., Seth, S. \& Vaz, A. (2014) Global Multidimensional Poverty Index 2014. OPHI Briefing 21, Oxford: University of Oxford.

Allen, E.R. (2016) Analysis of Trends and Challenges in the Indonesian Labor Market. ADB Papers on Indonesia No. 16. Asian Development Bank, Metro Manila, Philippines.

Alwarritzi, W., Nanseki, T. \& Chomei, Y. (2015) Impact of oil palm expansion on farmers' crop income and poverty reduction in Indonesia: An application of propensity score matching. The Journal of Agricultural Science 8, 119.

Austin, P.C. (2011) Optimal caliper widths for propensity-score matching when estimating differences in means and differences in proportions in observational studies. Pharmaceutical Statistics 10, 150161.

Basiron, Y. (2007) Palm oil production through sustainable plantations. European Journal of Lipid Science and Technology 109, 289-95

Belcher, B., Achdiawan, R. \& Dewi, S. (2015) Forest-based livelihoods strategies conditioned by market remoteness and forest proximity in Jharkhand, India. World Development 66, 269-279.

Blaber-Wegg, T., Hodbod, J. \& Tomei, J. (2015) Incorporating equity into sustainability assessments of biofuels. Current Opinion in Environmental Sustainability 14, 180-186.

BPS (Bureau of Statistic Indonesia) (2010) Sensus Penduduk 2010. Jakarta, Indonesia.

BPS (Bureau of Statistic Indonesia) (2015) Village Potential Statistics (PODES) 2000, 2003, 2005, 2008, and 2014. Jakarta, Indonesia.

Budiharta, S., Meijaard, E., Wells, J.A., Abram, N.K. \& Wilson, K.A. (2016) Enhancing feasibility: Incorporating a socio-ecological systems framework into restoration planning. Environmental Science \& Policy 64, 83-92.

Byerlee, D., Falcon, W.P. \& Naylor, R.L. (2017) The Tropical Oil Crop Revolution: Food, Feed, Fuel, and Forests. Oxford University Press, Oxford, UK.

Carlson, K.M., Curran, L.M., Asner, G.P., Pittman, A.M., Trigg, S.N. et al. (2013) Carbon emissions from forest conversion by Kalimantan oil palm plantations. Nature Climate Change 3, 283-287.

Carlson, K.M., Heilmayr, R., Gibbs, H.K., Noojipady, P., Burns, D.N. et al. (2018) Effect of oil palm sustainability certification on deforestation and fire in Indonesia. Proceedings of the National Academy of Sciences 115, 121-126.

Carter, C., Finley, W., Fry, J., Jackson, D. \& Willis, L. (2007) Palm oil markets and future supply. European Journal of Lipid Science and Technology 109, 4307-314.

Castiblanco, C., Etter, A. \& Ramirez, A. (2015) Impacts of oil palm expansion in Colombia: What do socioeconomic indicators show? Land Use Policy 44, 31-43.

Cattau, M.E., Marlier, M.E. \& DeFries, R. (2016) Effectiveness of Roundtable on Sustainable Palm Oil (RSPO) for reducing fires on oil palm concessions in Indonesia from 2012 to 2015 . Environmental Research Letters 11, 105007. 
CNN Indonesia (2017) KPK Temukan 63 Ribu Wajib Pajak Industri Sawit Kemplang Pajak. 4 May. Available at: https://www.cnnindonesia.com/nasional/20170503174824-12-212023/kpk-temukan-63-ribuwajib-pajak-industri-sawit-kemplang-pajak.

Colchester, M., Jiwan, N., Andiko, Sirait, M., Firdaus, A.Y. et al. (2006) Promised Land. Palm Oil and Land Acquisition in Indonesia: Implications for Local Communities and Indigenous Peoples. Forest Peoples Programme / Perkumpulan Sawit Watch, Jakarta, Indonesia.

Comte, I., Colin, F., Whalen, J.K., Grünberger, O. \& Caliman, J.P. (2012) Agricultural practices in oil palm plantations and their impact on hydrological changes, nutrient fluxes and water quality in Indonesia: A review. Advances in Agronomy 116, 71.

Cooke, M.F. (2012) In the name of poverty alleviation: Experiments with oil palm smallholders and customary land in Sabah, Malaysia. Asia Pacific Viewpoint 53, 240-253.

Costanza, R., Fisher, B., Ali, S., Beer, C., Bond, L. et al. (2007) Quality of life: An approach integrating opportunities, human needs, and subjective well-being. Ecological Economics 61, 267-276.

Cramb, R.A., Colfer, C.J.P., Dressler, W., Laungaramsri, P., Le, Q.T., Mulyoutami, E. et al. (2009) Swidden transformations and rural livelihoods in Southeast Asia. Human Ecology 37, 323-346.

Daniel, T.C., Muhar, A., Arnberger, A., Aznar, O., Boyd, J.W. et al. (2012) Contributions of cultural services to the ecosystem services agenda. Proceedings of the National Academy of Sciences 109, 8812-8819.

Dehejia, R.H. \& Wahba, S. (2002) Propensity score-matching methods for nonexperimental causal studies. Review of Economics and Statistics 84, 151-161.

Dennis, R.A. \& Colfer, C.P. (2006) Impacts of land use and fire on the loss and degradation of lowland forest in 1983-2000 in East Kutai District, East Kalimantan, Indonesia. Singapore Journal of Tropical Geography 27, 30-48.

Directorate General of Estate Crops Indonesia (2017) Tree Crop Estate Statistics of Indonesia 2015-2017: Palm Oil. Ministry of Agriculture, Jakarta.

Euler, M., Krishna, V., Schwarze, S., Siregar, H. \& Qaim, M. (2017) Oil palm adoption, household wellbeing, and nutrition among smallholder farmers in Indonesia. World Development 93, 219-235.

Euler, M., Schwarze, S., Siregar, H. \& Qaim, M. (2016) Oil palm expansion among smallholder farmers in Sumatra, Indonesia. Journal of Agricultural Economics 67, 658-676.

Falconer, A., Mafira, T. \& Sutiyono, G. (2015) Improving Land Productivity through Fiscal Policy: Early Insights on Taxation in the Palm Oil Supply Chain. Climate Policy Initiative. Available at:

https://climatepolicyinitiative.org/wp-content/uploads/2015/12/Full-Report-English-Early-Insightson-Taxation-in-the-Palm-Oil-Supply-Chain.pdf.

Ferraro, P.J. (2009) Counterfactual thinking and impact evaluation in environmental policy. New Directions for Evaluation 2009, 75-84.

Feintrenie, L., Chong, W.K. \& Levang, P. (2010) Why do farmers prefer oil palm? Lessons learnt from Bungo district, Indonesia. Small-Scale Forestry 9, 379-396.

Fick, S.E. \& Hijmans, R.J. (2017) WorldClim 2: new 1-km spatial resolution climate surfaces for global land areas. International Journal of Climatology 37, 4302-4315.

Food and Agriculture Organization of the United Nations Statistics Division (FAOSTAT) (2016) Crops; Indonesia; Oil, Palm and Oil, Palm Fruit; Average Production of Commodity; 1990-2014. Available at: http://faostat3.fao.org/browse/Q/QC/E.

Friedman, J.H. (2001) Greedy function approximation: a gradient boosting machine. The Annals of Statistics 29, 1189-1232.

Gatto, M., Wollni, M., Asnawi, R. \& Qaim, M. (2017) Oil palm boom, contract farming, and rural economic development: Village-level evidence from Indonesia. World Development 95, 127-140. 
Gaveau, D.L.A., Salim, M. \& Arjasakusuma, S. (2016a) Deforestation and Industrial Plantations Development in Borneo. Center for International Forestry Research (CIFOR) Dataverse, V1.

Gaveau, D.L., Sheil, D., Husnayaen, M.A.S., Arjasakusuma, S., Ancrenaz, M. et al. (2016b). Rapid conversions and avoided deforestation: examining four decades of industrial plantation expansion in Borneo. Scientific Reports 6, 32017.

Geospatial Information Agency (BIG) (2016) Peta Propinsi Kalimantan Barat, Kalimantan Selatan, Kalimantan Tengah, Kalimantan Timur, dan Kalimantan Utara. Jakarta, Indonesia.

Hansen, M.C., Potapov, P.V., Moore, R., Hancher, M., Turubanova, S. et al. (2013) High-resolution global maps of 21st-century forest cover change. Science 342, 850-853.

Hodbod, J. \& Tomei, J. (2013) Demystifying the social impacts of biofuels at local levels: Where is the evidence? Geography Compass 7, 478-488.

Huffman, G.J., Bolvin, D.T., Nelkin, E.J., Wolff, D.B., Adler, R.F. et al. (2007) The TRMM multisatellite precipitation analysis (TMPA): Quasi-global, multiyear, combined-sensor precipitation estimates at fine scales. Journal of Hydrometeorology 8, 38-55.

Ickowitz, A., Rowland, D., Powell, B., Salim, M.A., \& Sunderland, T. (2016) Forests, trees, and micronutrient-rich food consumption in Indonesia. PLOS ONE 11, e0154139.

Jarvis, A., Reuter, H.I., Nelson, A. \& Guevara, E. (2008) Hole-filled SRTM for the Globe Version 4. URL: http://srtm.csi.cgiar.org.

Jelsma, I., Schoneveld, G.C., Zoomers, A. \& Van Westen, A.C.M. (2017) Unpacking Indonesia's independent oil palm smallholders: An actor-disaggregated approach to identifying environmental and social performance challenges. Land Use Policy 69, 281-297.

Junaidi (2012) Perkembangan Desa-Desa Eks Transmigrasi dan Interaksi dengan Wilayah Sekitarnya Serta Kebijakan ke Depan (Kajian di Provinsi Jambi). PhD Thesis. Bogor Agricultural University (IPB), Bogor. Available at: https://repository.ipb.ac.id/jspui/bitstream/123456789/58350/1/2012jun.pdf.

Keele, L.J. (2014) Perform Rosenbaum Bounds Sensitivity Tests for Matched and Unmatched Data. R Package Version 2.1.

Kinnaird, M.F., Sanderson, E.W., O'brien, T.G., Wibisono, H.T. \& Woolmer, G. (2003) Deforestation trends in a tropical landscape and implications for endangered large mammals. Conservation Biology 17, 245-257.

Klasen, S., Meyer, K.M., Dislich, C., Euler, M., Faust, H. et al. (2016) Economic and ecological trade-offs of agricultural specialization at different spatial scales. Ecological Economics 122, 111-120.

Kompas (2018) Presiden Jokowi: Banyak yang Ketakutan dengan Kebijakan Satu Peta. 11 December. Available at: https://nasional.kompas.com/read/2018/12/11/13471861/presiden-jokowi-banyakyang-ketakutan-dengan-kebijakan-satu-peta.

Kremen, C., Iles, A. \& Bacon, C. (2012) Diversified farming systems: an agroecological, systems-based alternative to modern industrial agriculture. Ecology and Society 17, 44.

Krishna, V., Euler, M., Siregar, H. \& Qaim, M. (2017) Differential livelihood impacts of oil palm expansion in Indonesia. Agricultural Economics 48, 639-653.

Lee, B.K., Lessler, J. \& Stuart, E.A. (2010) Improving propensity score weighting using machine learning. Statistics in Medicine 29, 337-346.

Lee, J.S.H., Ghazoul, J., Obidzinski, K. \& Koh, L.P. (2014) Oil palm smallholder yields and incomes constrained by harvesting practices and type of smallholder management in Indonesia. Agronomy for Sustainable Development 34, 501-513.

Li, T.M. (2016) Situating transmigration in Indonesia's oil palm labour regime. In: The Oil Palm Complex: Smallholders, Agribusiness and the State in Indonesia and Malaysia (eds. R. Cramb \& J. McCarthy), pp. 354-377. Singapore: NUS Press. 
Linkie, M., Smith, R.J. \& Leader-Williams, N. (2004) Mapping and predicting deforestation patterns in the lowlands of Sumatra. Biodiversity and Conservation 13, 1809-1818.

Margono, B.A., Potapov, P.V., Turubanova, S., Stolle, F. \& Hansen, M.C. (2014) Primary forest cover loss in Indonesia over 2000-2012. Nature Climate Change 4, 730-735.

McCarthy, J.F., Gillespie, P. \& Zen, Z. (2012) Swimming upstream: local Indonesian production networks in "globalized" palm oil production. World Development 40, 555-569.

Meijaard, E., Achdiawan, R., Wan, M. \& Taber, A. (2014) Rattan. The Decline of a Once-Important NonTimber Forest Product in Indonesia. CIFOR Occasional Paper No. 101. Center for International Forestry Research (CIFOR), Bogor, Indonesia.

Meijaard, E., Garcia-Ulloa, J., Sheil, D., Carlson, K., Wich, S.A. et al. (2018) Oil Palm and Biodiversity - A Situation Analysis. IUCN Oil Palm Task Force, Gland, Switzerland.

Meijerink, G.W., Langeveld, J.W.A. \& Hellegers, P.J.G.J. (2008) Biofuels and Water: An Exploration. Wageningen UR.

Mertz, O., Padoch, C., Fox, J., Cramb, R.A., Leisz, S.J. et al. (2009) Swidden change in Southeast Asia: understanding causes and consequences. Human Ecology 37, 259-264.

Merz, B., Aerts, J.C.J.H., Arnbjerg-Nielsen, K., Baldi, M., Becker, A. et al. (2014) Floods and climate: emerging perspectives for flood risk assessment and management. Natural Hazards and Earth System Sciences 14, 1921-1942.

Ministry of Environment and Forestry Indonesia (MEF) (2010) Peta Kawasan Hutan. Jakarta, Indonesia.

Ministry of Environment and Forestry Indonesia (MEF) (2016) Peta Penutupan Lahan (PPL) 1990-2015. Jakarta, Indonesia.

Ministry of Environment and Forestry Indonesia (MEF) (2017) Peta Kesatuan Hidrologi Gambut. Jakarta.

Moeliono, M. \& Limberg, G. (2012) The Decentralization of Forest Governance: Politics, Economics and the Fight for Control of Forests in Indonesian Borneo. Routledge.

Mongabay (2016) Menanti Moratorium Sawit, Berikut Alasan Mengapa Kebijakan Ini Urgen. Mongabay Indonesia. 22 August. Available at: http://www.mongabay.co.id/2016/08/22/menanti-moratoriumsawit-berikut-alasan-mengapa-kebijakan-ini-urgen.

Mongabay (2018a) Indonesia's Anti-Graft Agency 'Eager to Intervene' in Palm Oil Sector. 25 October. Available at: https://news.mongabay.com/2018/10/indonesias-anti-graft-agency-eager-tointervene-in-palm-oil-sector.

Mongabay (2018b) Ketika Kebijakan Satu Peta Rilis, Bagaimana Akses Publik? 22 December. Available at: https://www.mongabay.co.id/2018/12/22/ketika-kebijakan-satu-peta-rilis-bagaimana-aksespublik/.

Morgans, C.L., Meijaard, E., Santika, T., Law, E., Budiharta, S. et al. (2018) Evaluating the effectiveness of palm oil certification in delivering multiple sustainability objectives. Environmental Research Letters 13, 064032.

Noojipady, P., Morton, D.C., Schroeder, W., Carlson, K.M., Huang, C. et al. (2017) Managing fire risk during drought: The influence of certification and El Niño on fire-driven forest conversion for oil palm in Southeast Asia. Earth System Dynamics 8, 749.

Obidzinski, K., Andriani, R., Komarudin, H. \& Andrianto, A. (2012) Environmental and social impacts of oil palm plantations and their implications for biofuel production in Indonesia. Ecology and Society 17, 25.

Obidzinski, K., Dermawan, A. \& Hadianto, A. (2014) Oil palm plantation investments in Indonesia's forest frontiers: limited economic multipliers and uncertain benefits for local communities. Environment, Development and Sustainability 16, 1177-1196. 
Oldeman, L.R. \& Frere, M. (1982) Technical Report on a Study of the Agroclimatology of the Humid Tropics of Southeast Asia. Food \& Agriculture Organizations.

Palupi, S., Sukapti, Y.S., Maemunah, S., Prasetyohadi, P., Tømte, A. et al. (2017) Privatisasi Transmigrasi dan Kemitraan Plasma Menopang Industri Sawit: Resiko Hak Asasi Manusia dalam Kebijakan Transmigrasi dan Kemitraan Plasma di Sektor Industri Perkebunan Sawit. The Institute for Ecosoc Rights \& Norwegian Center for Human Rights. Jakarta. Available at: https://www.jus.uio.no/smr/english/about/id/news/docs/buku_privatisasi_transmigrasi_2017.pdf.

Phalan, B. (2009) The social and environmental impacts of biofuels in Asia: an overview. Applied Energy 86, S21-S29.

Potter, L. (2009) Oil palm and resistance in West Kalimantan, Indonesia. In: Agrarian Angst and Rural Resistance in Contemporary Southeast Asia (eds. Caouette, D. \& Turner S.), pp. 125-154. Routledge.

Potter, L. (2012) New transmigration 'paradigm' in Indonesia: Examples from Kalimantan. Asia Pacific Viewpoint 53, 272-287.

Resosudarmo, I.A.P. (2004) Closer to people and trees: will decentralisation work for the people and the forests of Indonesia? The European Journal of Development Research 16, 110-132.

Ridgeway, G., Southworth, M.H. \& R Development Unit (2015) Generalized Boosted Regression Models. R package version 2.1.1.

Rist, L., Feintrenie, L. \& Levang, P. (2010) The livelihood impacts of oil palm: smallholders in Indonesia. Biodiversity Conservation 19, 1009-1024.

Ruiz-Pérez, M., Belcher, B., Achdiawan, R., Alexiades, M., Aubertin, C. et al. (2004) Markets drive the specialization strategies of forest peoples. Ecology and Society $9,4$.

Rosenbaum, P.R. (2005) Heterogeneity and causality: Unit heterogeneity and design sensitivity in observational studies. The American Statistician 59, 147-152.

Shackleton, S., Delang, C.O. \& Angelsen, A. (2011) From subsistence to safety nets and cash income: exploring the diverse values of non-timber forest products for livelihoods and poverty alleviation. In: Non-Timber Forest Products in the Global Context (eds. Shackleton, S., Shackleton, C. \& Shanley, P.), pp. 55-81. Berlin: Springer.

Santika, T., Ancrenaz, M., Wilson, K.A., Spehar, S., Abram, N. et al. (2017a) First integrative trend analysis for a great ape species in Borneo. Scientific Reports 7, 4839.

Santika, T., Meijaard, E., Budiharta, S., Law, E.A., Kusworo, A. et al. (2017b) Community forest management in Indonesia: Avoided deforestation in the context of anthropogenic and climate complexities. Global Environmental Change 46, 60-71.

Santika, T., Meijaard, E. \& Wilson, K.A. (2015) Designing multifunctional landscapes for forest conservation. Environmental Research Letters 10, 114012.

Scoones, I. (1998) Sustainable Rural Livelihoods: A Framework for Analysis. IDS Working Paper 72. Sussex: Brighton Institute of Development Studies, University of Sussex.

Sekhon, J.S. (2015) Multivariate and Propensity Score Matching with Balance Optimization. R package version 4.9-2.

Sen, A. (1985) Commodities and Capabilities. Amsterdam, North-Holland.

Sheil, D., Casson, A., Meijaard, E., Van Noordwjik, M., Gaskell, J. et al. (2009) The Impacts and Opportunities of Oil Palm in Southeast Asia: What Do We Know and What Do We Need to Know? CIFOR Occasional Paper No. 51. Center for International Forestry Research (CIFOR), Bogor, Indonesia.

Shete, M. \& Rutten, M. (2015) Impacts of large-scale farming on local communities' food security and income levels-Empirical evidence from Oromia Region, Ethiopia. Land Use Policy 47, 282-292. 
Singh, R.P., Ibrahim, M.H., Esa, N. \& Iliyana, M.S. (2010) Composting of waste from palm oil mill: a sustainable waste management practice. Reviews in Environmental Science and Bio/Technology $\mathbf{9}$, 331-344.

Sirait, M. (2009) Indigenous Peoples and Oil Palm Plantation Expansion in West Kalimantan, Indonesia. The Hague: Cordaid Memisa.

Tempo (2016) Baru Sepertiga Perusahaan Sawit Bayar Pajak. 24 August. Available at: https://bisnis.tempo.co/read/798659/baru-sepertiga-perusahaan-sawit-bayar-pajak/full\&view=ok.

Tempo (2017a) Industry Minister Airlangga Hartarto: Our Objective is to Save the Industry. May 23. Available at: https://magz.tempo.co/konten/2017/05/23/LU/33190/Industry-Minister-AirlanggaHartarto-Our-Objective-is-to-Save-the-Industry/40/17.

Tempo (2017b) Minister of the Environment and Forestry Siti Nurbaya: Protecting Peatlands is an Absolute Must. May 23. Available at: https://magz.tempo.co/konten/2017/05/23/LU/33189/Minister-of-theEnvironment-and-Forestry-Siti-Nurbaya-Protecting-Peatlands-is-an-Absolute-Must/40/17.

Tempo (2017c) KPK: Pengelolaan Komoditas Kelapa Sawit Rawan Korupsi. 24 April. Available at: https://nasional.tempo.co/read/869099/kpk-pengelolaan-komoditas-kelapa-sawit-rawankorupsi/full\&view=ok.

Times Indonesia (2018) Ekspedisi Gubernur: Bang Midji Siapkan Moratorium Sawit di Kalbar, Ini Alasannnya. 15 October. Available at:

https://www.timesindonesia.co.id/read/186159/20181015/153742/ekspedisi-gubernur-bang-midjisiapkan-moratorium-sawit-di-kalbar-ini-alasannnya

Tosca, M.G., Randerson, J.T., Zender, C.S., Nelson, D.L., Diner, D.J. et al. (2011) Dynamics of fire plumes and smoke clouds associated with peat and deforestation fires in Indonesia. Journal of Geophysical Research: Atmospheres 116, D08207.

United Nations (1996) Report of The World Summit for Social Development. United Nations: New York, NY, USA. Available at: https://www.un.org/development/desa/dspd/world-summit-for-socialdevelopment-1995.html.

United Nations General Assembly (2014). Open Working Group Proposal for Sustainable Development Goals (A/68/970). United Nations: New York, NY, USA.

Villela, A.A., D'Alembert, B.J., Rosa, L.P. \& Freitas, M.V. (2014) Status and prospects of oil palm in the Brazilian Amazon. Biomass and Bioenergy 67, 270-278.

Wakker, E., Watch, S. \& de Rozario, J. (2004) Greasy Palms: The Social and Ecological Impacts of LargeScale Oil Palm Plantation Development in Southeast Asia. AIDEnvironment, Amsterdam. Available at: https://www.cabdirect.org/cabdirect/abstract/20056701996.

Wells, J.A., Wilson, K.A., Abram, N.K., Nunn, M., Gaveau, D.L. et al. (2016) Rising floodwaters: mapping impacts and perceptions of flooding in Indonesian Borneo. Environmental Research Letters 11, 064016.

Zen, Z., Barlow, C., Gondowarsito, R. \& McCarthy, J.F. (2016) Interventions to promote smallholder oil palm and socio-economic improvement in Indonesia. In: The Oil Palm Complex: Smallholders, Agribusiness and the State in Indonesia and Malaysia (eds. R. Cramb \& J. McCarthy), pp. 78-108. Singapore: NUS Press.

Zoomers, A., van Noorloos, F., Otsuki, K., Steel, G. \& van Westen, G. (2017) The rush for land in an urbanizing world: From land grabbing toward developing safe, resilient, and sustainable cities and landscapes. World Development 92, 242-252. 


\section{Appendix A. Supplementary Figures}

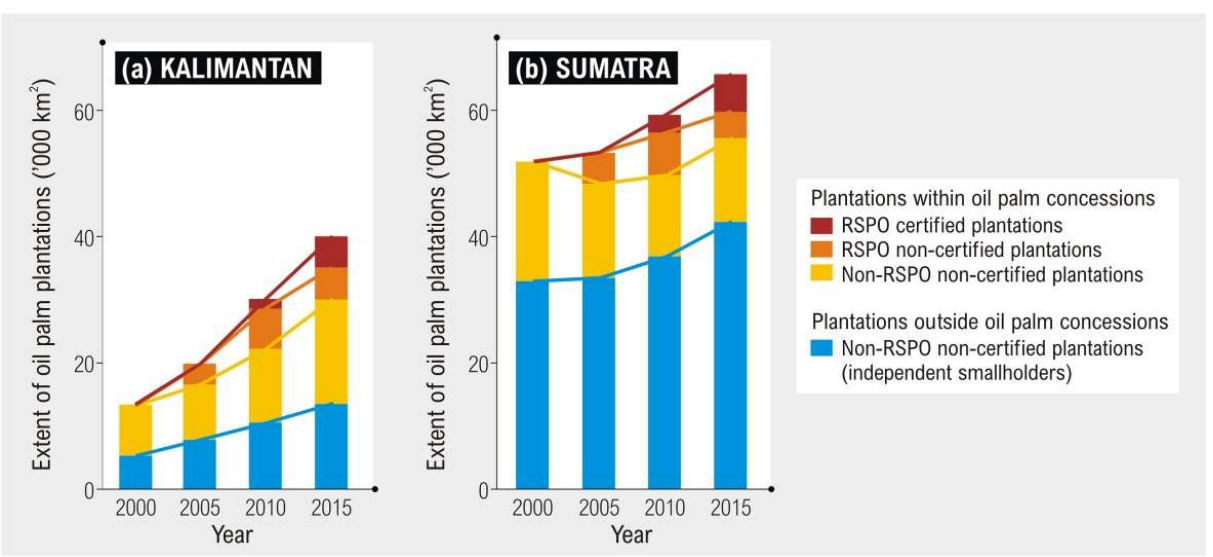

Fig. A1. The change in the extent of oil palm plantations in (a) Kalimantan, and (b) Sumatra, every 5 years between 2000 and 2015, by type of plantation holder: Roundtable on Sustainable Palm Oil (RSPO) certified plantations, RSPO non-certified plantations, Non-RSPO non-certified plantations within oil palm concessions, and Non-RSPO non-certified outside oil palm concessions (independent smallholders).

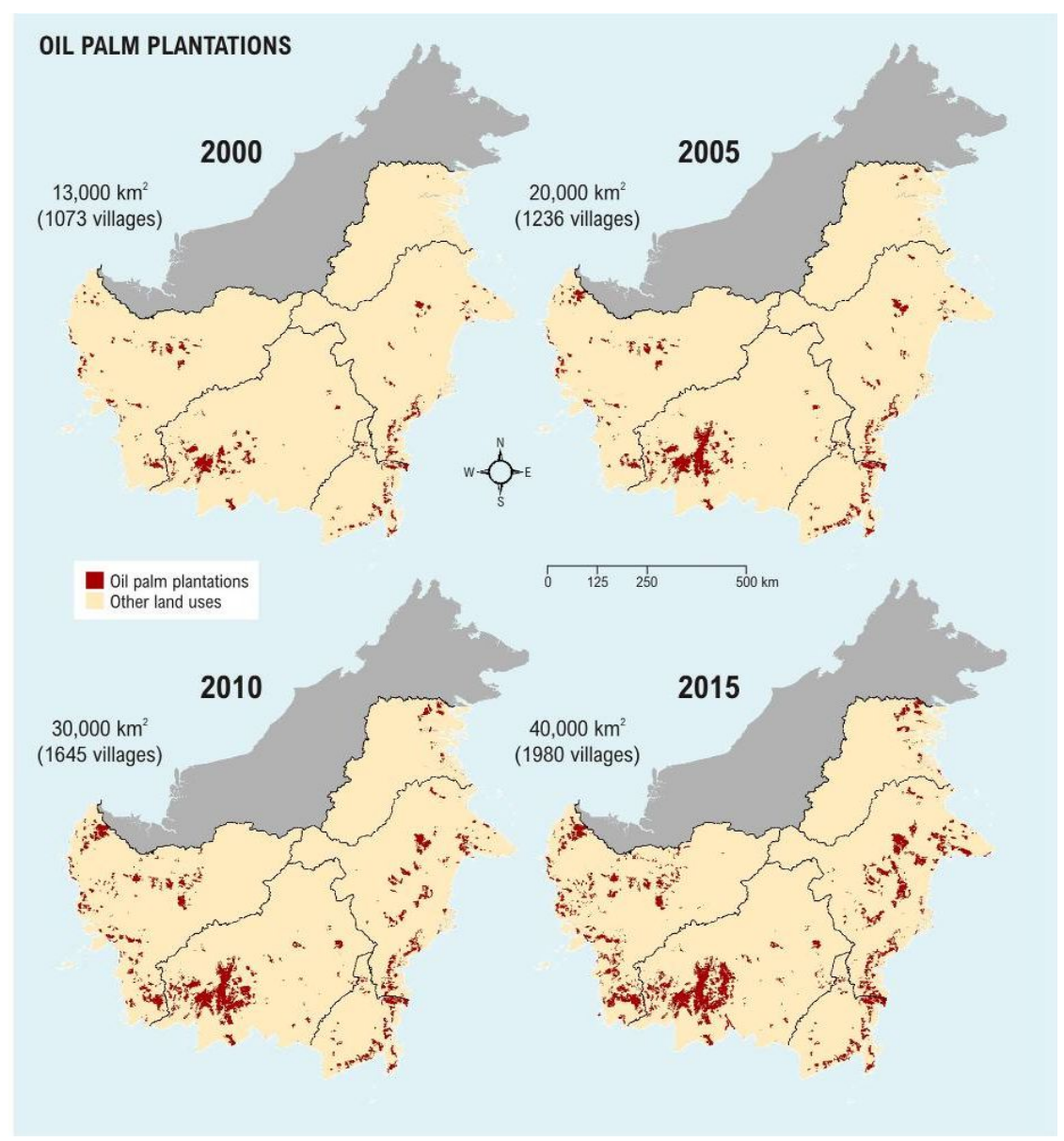

Fig. A2. Change in the distribution of oil palm plantations in Kalimantan every five years between 2000 and 2015. 

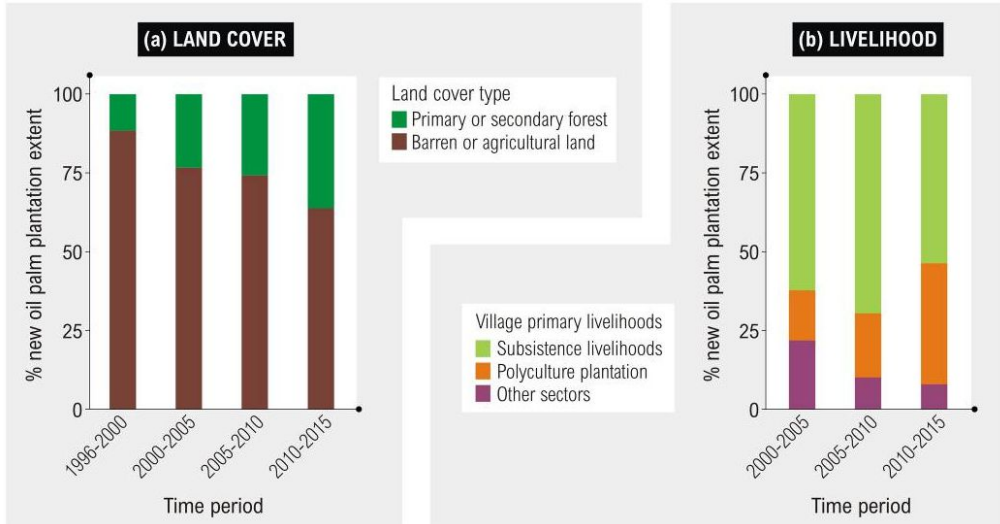

Fig. A3. (a) Land cover types, including primary or secondary forest, barren or agricultural land, and (b) primary livelihood of communities, including subsistence-based livelihoods, plantation (polyculture), and other sectors (horticulture, aquaculture, agricultural services, and non-agricultural sectors), where new oil palm plantations have been developed in Kalimantan in 1996-2000, 2000-2005, 2005-2010, and 2010-2015.
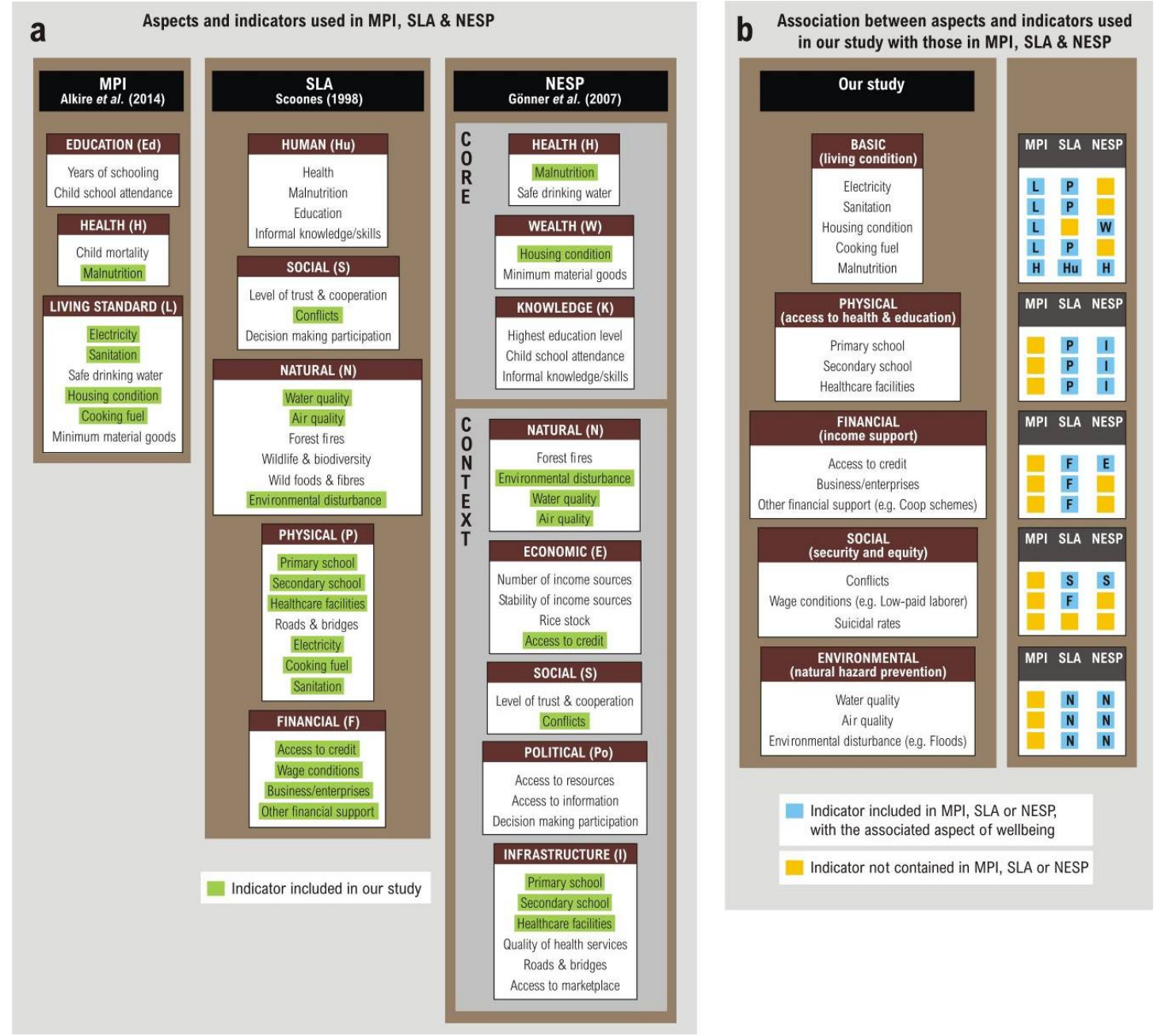

Fig. A4. (a) Aspects (dimensions) and indicators of well-being used in the Multidimensional Poverty Index (MPI, Alkire et al. 2014), the Sustainable Livelihood Approach (SLA, Scoones 1998), and the Nested Spheres of Poverty (NESP, Gonner et al. 2007). (b) Association between aspects and indicators used in our study with those encapsulated in MPI, SLA and NESP, with the associated aspect represented by the capital letter in the second column. For MPI, the aspects include: Education (Ed), Health (H), and Living standards (L). For SLA, the aspects include: Human (Hu), Social (S), Natural (N), Physical (P) and Financial (F). For NESP, the Core includes: Health $(\mathrm{H})$, Wealth (W), and Knowledge (K); and the Context includes: Natural (N), Economic (E), Social (S), Political (Po), and Infrastructure (I). 

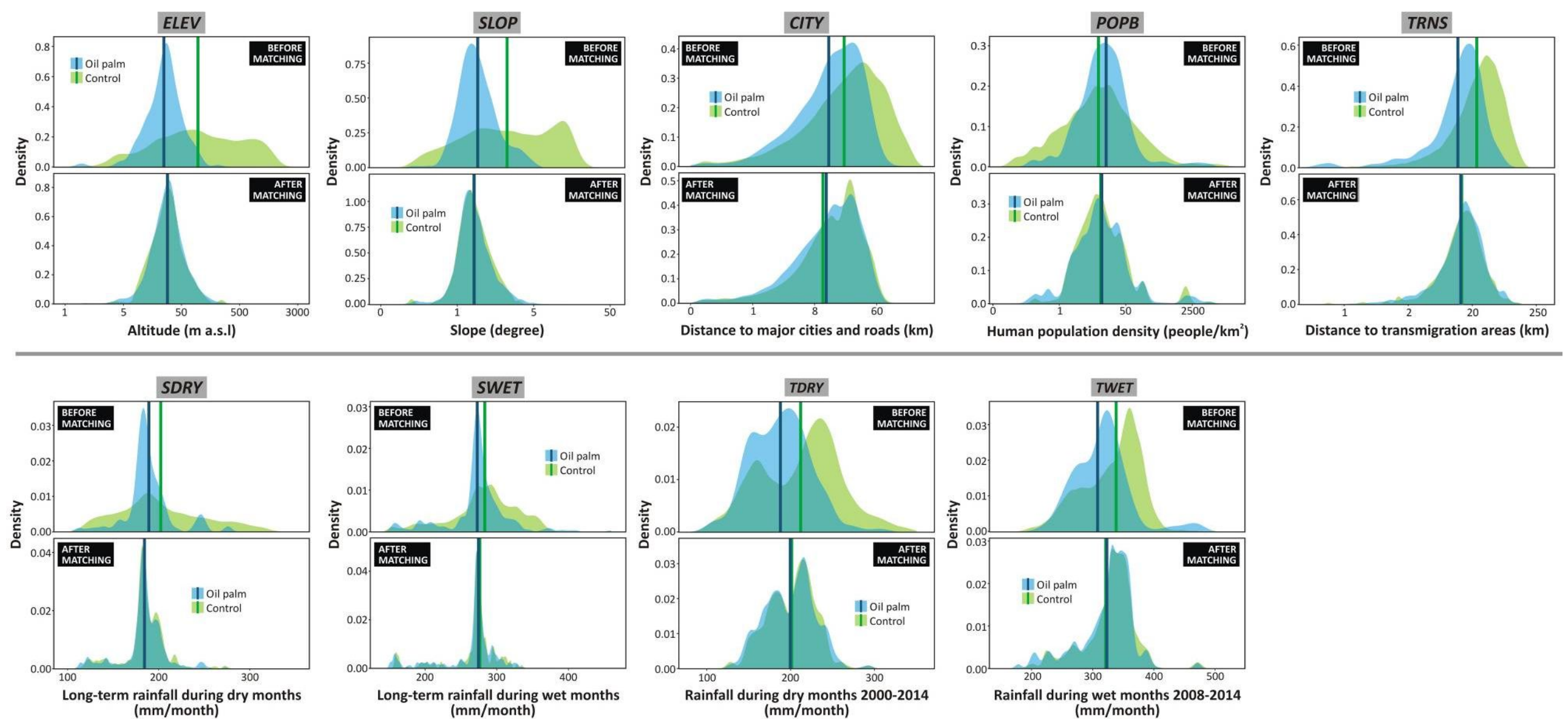

Fig. A5. The distributions of continuous variables characterizing oil palm plantation and control villages in Kalimantan, before and after matching, aggregated across time periods used in the analyses. Variables include: mean elevation (ELEV), mean slope (SLOP), mean distance to large cities or arterial roads (CITY), mean human population density $(P O P B)$, mean distance to transmigration areas (TRNS), mean long-term mean monthly rainfall during the dry and wet season (SDRY and SWET), and mean monthly mean rainfall during the dry and wet season between 2000 and 2014 (TDRY and TWET). The degree of overlap between the distributions of variables for oil palm villages and controls increased after matching, indicating increased similarity in the characteristics of oil palm villages and matched controls. Vertical lines indicate the mean value for oil-palm villages and controls, with the gap between the two lines decreased after matching. 
a BASIC WELL-BEING
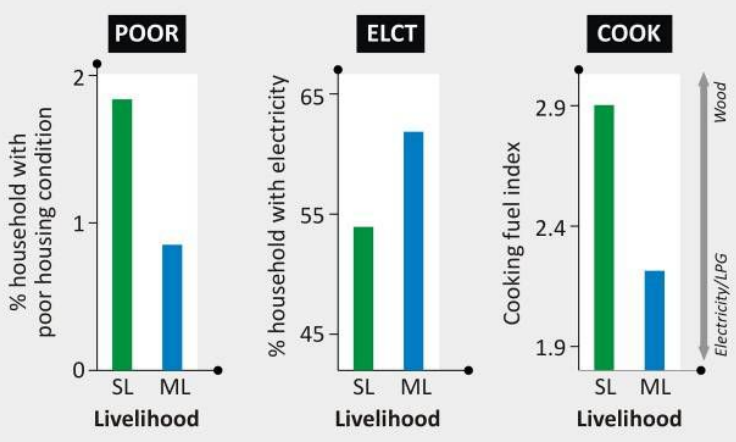

TOLT

MLNT
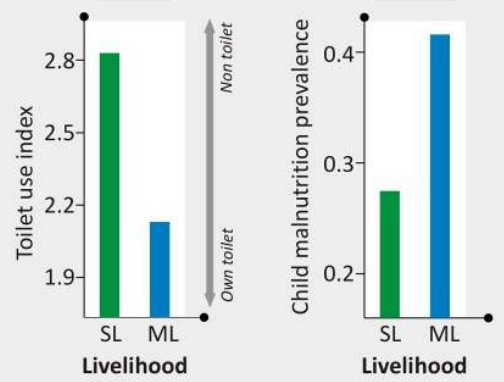

Primary livelihoods

SL (Subsistence-based livelihoods)

ML (Market-oriented livelihoods)

\section{b PHYSiCAL WELL-BEING}
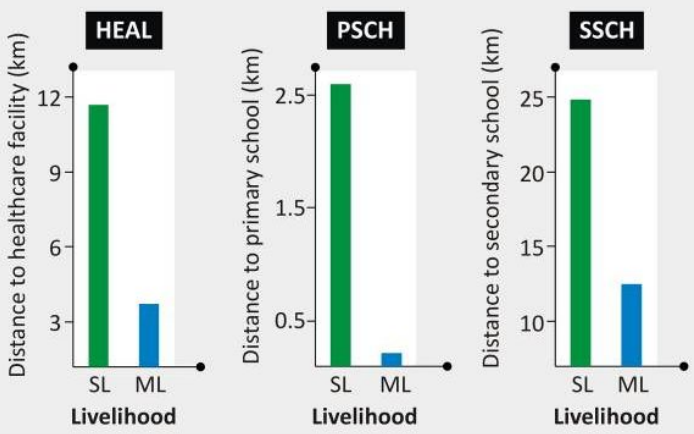

C finANCIAL WELL-BEING
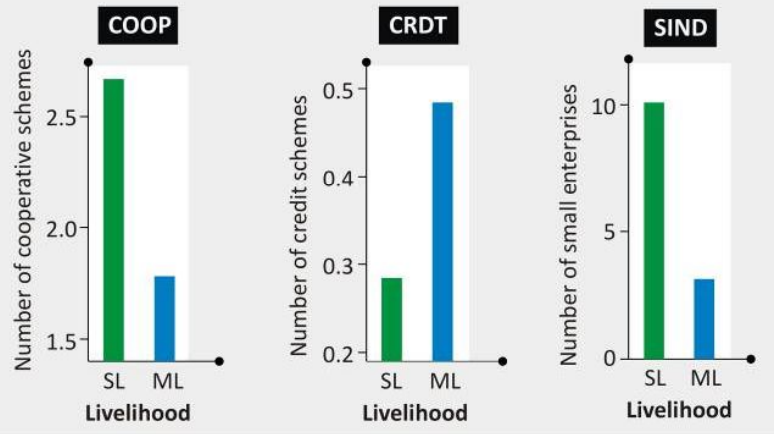

d SOCIAL WELL-BEING
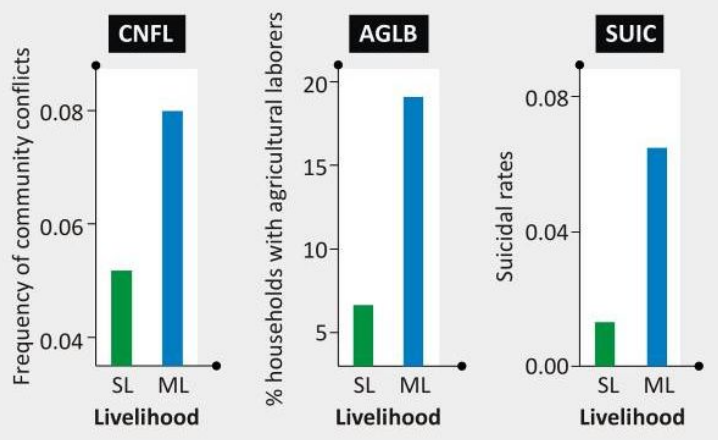

\section{Q ENVIRONMENTAL WELL-BEING}
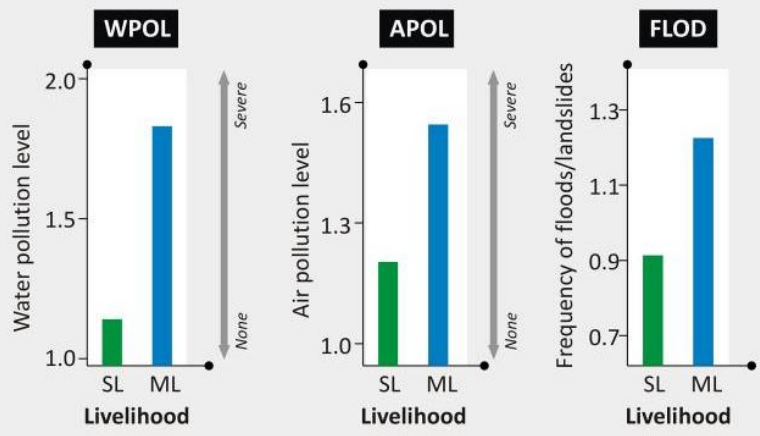

Fig. A6. Baseline community welfare prior to oil-palm plantation developments: (a) Basic wellbeing (living condition), (b) Physical wellbeing (infrastructure), (c) Financial wellbeing (income support), (d) Social well-being (security and social equity), and (e) Environmental wellbeing (prevention of natural hazards), in villages with different main livelihood sectors: subsistence-based livelihoods (SL; swidden farming of dryland rice (intercropped with banana, maize, and cassava, and typically supplemented by market exchange for forest and/or agroforest products) and inland fishing) and market-oriented livelihoods (ML; including polyculture plantations (e.g. coffee, rubber, oil palm, coconut), horticulture, aquaculture, agricultural services, and non-agricultural sectors). Detail explanation of socioeconomic indicator is provided in Table 1. 

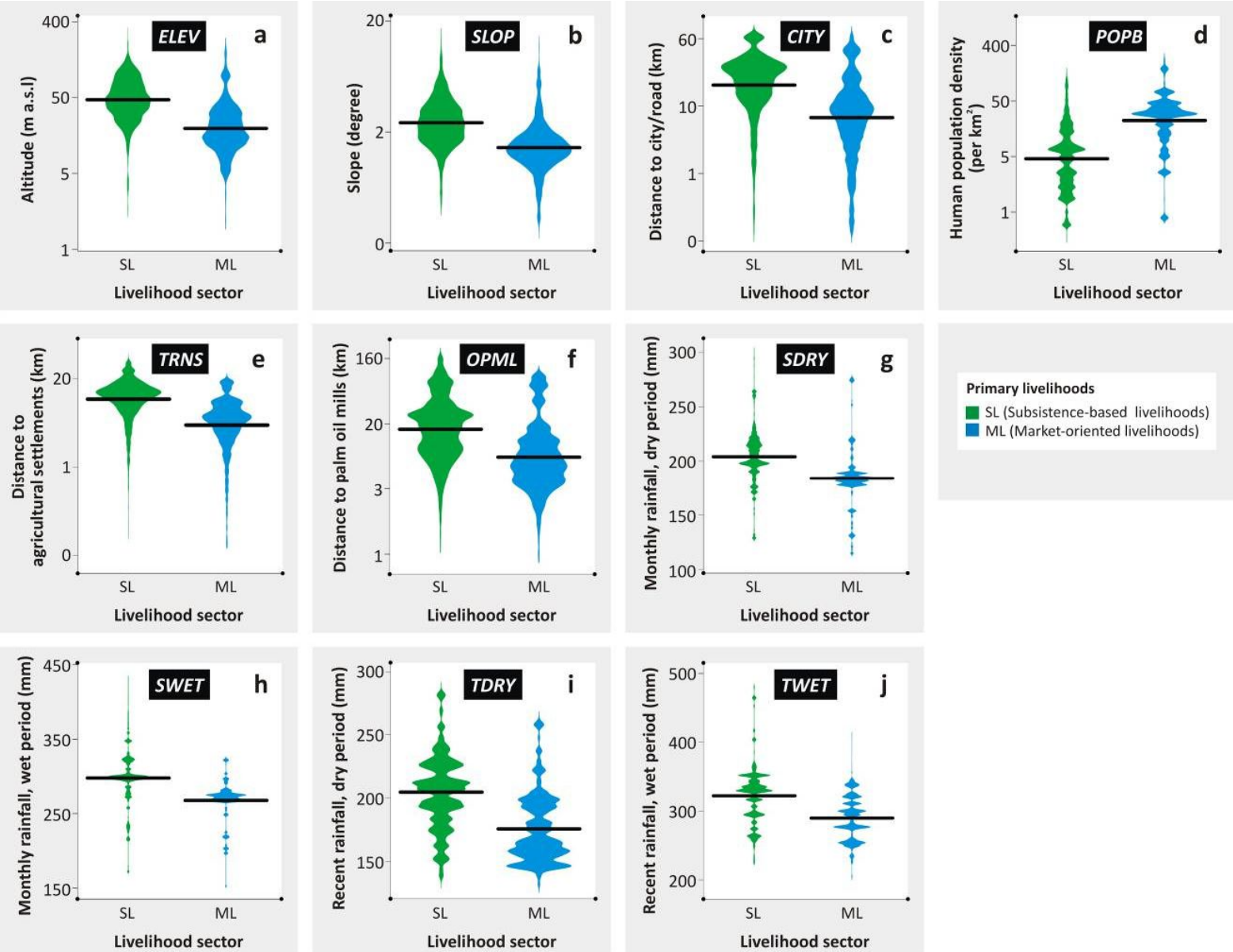

Fig. A7. Biophysical characteristics of villages with different main livelihood sectors: subsistence-based livelihoods (SL; swidden farming of dryland rice (inter-cropped with banana, maize, and cassava, and typically supplemented by market exchange for forest and/or agroforest products) and inland fishing) and marketoriented livelihoods (ML; including polyculture plantations (e.g. coffee, rubber, oil palm, coconut), horticulture, aquaculture, agricultural services, and non-agricultural sectors). Biophysical characteristics include: (a) elevation: $E L E V$, (b) slope: SLOP, (c) distance to major cities and roads: $C I T Y$, (d) human population density: $P O P B,(\mathrm{e})$ distance to transmigration areas: TRNS, (f) distance to palm-oil mills: $O P M L,(\mathrm{~g}-\mathrm{h})$ long term monthly rainfall during the dry and wet seasons: SDRY and SWET, and (i-j) monthly rainfall between 2000 and 2014 during the dry and wet seasons: TDRY and TWET. 


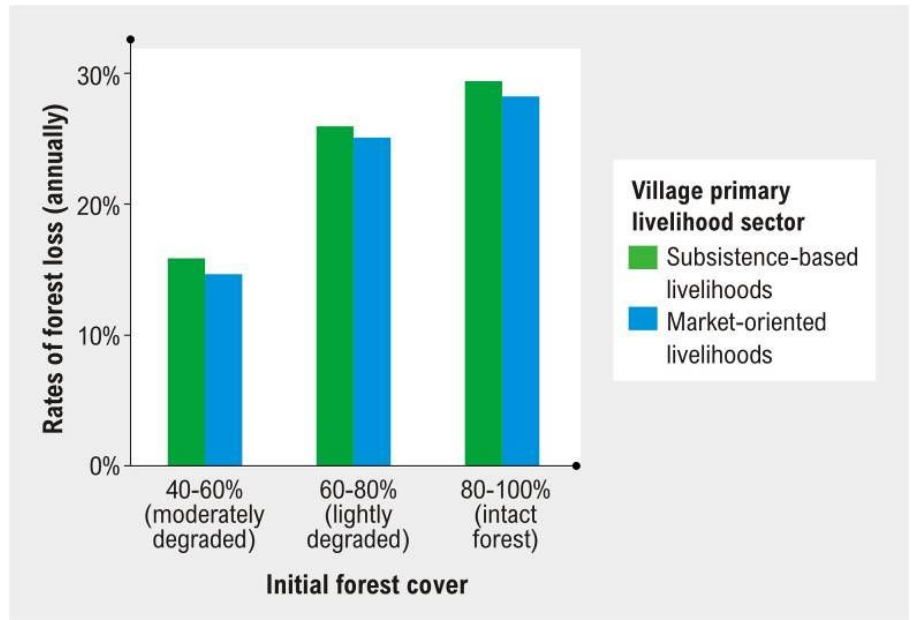

Fig. A8. The rates of annual forest loss over a five year period prior to oil palm developed between 2000 and 2014, by initial forest cover in villages where most communities had relied on subsistence-based livelihoods or market-oriented livelihoods.
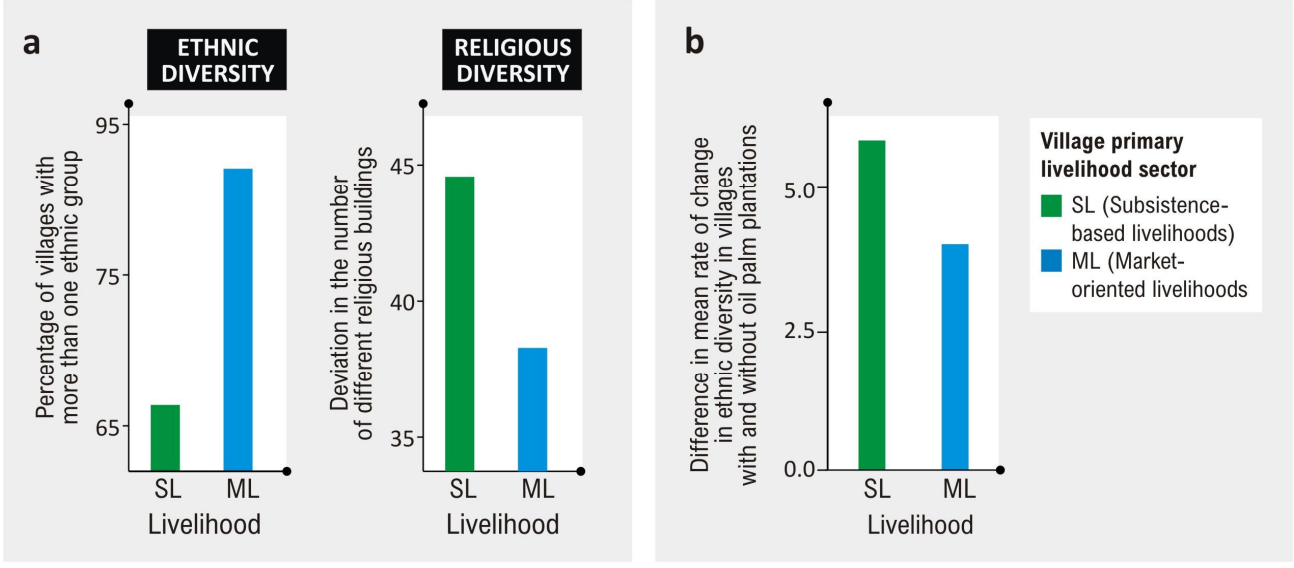

Fig. A9. (a) Ethnic and religious diversity of oil-palm villages where communities formerly relied on subsistencebased livelihoods (SL) and market-oriented livelihoods (ML). We used indicators of percentage of villages with more than one ethnic group (where higher value indicates higher ethnic diversity in communities) and deviation (i.e. standard deviation) in the number of different religious buildings (where lower value indicates more religiously diverse communities). (b) Difference in mean rate of change in ethnic diversity for villages with and without oil-palm development, where most communities formerly depend on subsistence-based livelihoods and market-oriented livelihoods. 


\section{Appendix B. Supplementary Tables}

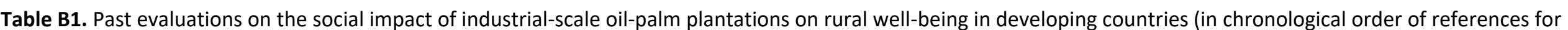

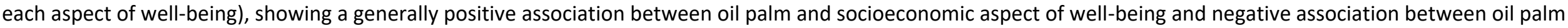
and social and environmental aspects of well-being.

\begin{tabular}{|c|c|c|c|c|c|c|c|}
\hline $\begin{array}{l}\text { Aspect of } \\
\text { well-being }\end{array}$ & $\begin{array}{l}\text { Indicator of } \\
\text { well-being }\end{array}$ & Study area & Time frame & $\begin{array}{c}\text { Case- } \\
\text { control } \\
\text { study } \\
\not\end{array}$ & $\begin{array}{c}\text { Subsistence } \\
\text {-based } \\
\text { livelihoods } \\
\S \\
\end{array}$ & $\begin{array}{l}\text { Oil palm } \\
\text { impact } \ddagger\end{array}$ & Reference \\
\hline \multirow[t]{21}{*}{ Socioeconomic } & \multirow{18}{*}{$\begin{array}{l}\text { Income, } \\
\text { consumption, } \\
\text { employment, } \\
\text { and } \\
\text { developments }\end{array}$} & 4 communities in West Kalimantan province & 2008 & $\mathrm{~N}$ & $Y$ & - & Sirait (2009) \\
\hline & & Bungo district, Jambi province, Sumatra & $2007-2009$ & $\mathrm{~N}$ & $\mathrm{~N}$ & + & Feintrenie et al. (2010) \\
\hline & & Bungo district, Jambi province, Sumatra & 2007-2009 & $\mathrm{N}$ & $\mathrm{N}$ & + & Rist et al. (2010) \\
\hline & & 78 villages in 8 provinces in Sumatra, Kalimantan \& Sulawesi & 2010 & $\mathrm{~N}$ & $\mathrm{~N}$ & + & Budidarsono et al. (2012) \\
\hline & & Dabat village, Sanggau district, West Kalimantan province & 2010 & $\mathrm{~N}$ & $\mathrm{~N}$ & + & Julia \& White (2012) \\
\hline & & Manokwari district, West Papua province & 2011 & $\mathrm{~N}$ & Y & + & Obidzinski et al. (2012) \\
\hline & & Kubu Raya district, West Kalimantan province & 2011 & $\mathrm{~N}$ & Y & - & Obidzinski et al. (2012) \\
\hline & & Boven Digoel district, Papua province & 2011 & $\mathrm{~N}$ & Y & - & Obidzinski et al. (2012) \\
\hline & & 3 oil palm estates in Riau province, Sumatra & 2012 & $\mathrm{~N}$ & $\mathrm{~N}$ & - & Sinaga (2013) \\
\hline & & 2 communities in Polochic Valley, Guatemala & 2009-2011 & $\mathrm{N}$ & $\mathrm{Y}$ & + & Mingorría et al. (2014) \\
\hline & & 1 oil palm estate in Bayelsa, Nigeria & 2013 & $\mathrm{~N}$ & $\mathrm{~N}$ & + & Ohimain et al. (2014) \\
\hline & & 271 households in Riau province, Sumatra & $1990-2015$ & Y & $\mathrm{N}$ & + & Alwarritzi et al. (2015) \\
\hline & & 100 municipalities in Colombia & $1993-2009$ & Y & YN & + & Castiblanco et al. (2015) \\
\hline & & 245 households in Jambi province, Sumatra & 2010 & $\mathrm{~N}$ & $\mathrm{~N}$ & + & Cahyadi \& Waibel (2016) \\
\hline & & Kutai Kertanegara district, East Kalimantan province & 2014 & $\mathrm{~N}$ & $\mathrm{~N}$ & + & Dharmawan et al. (2016) \\
\hline & & 682 households in Jambi province, Sumatra & 2012 & Y & $\mathrm{N}$ & + & Euler et al. (2017) \\
\hline & & 98 villages in Jambi province, Sumatra & $1992-2012$ & Y & $\mathrm{N}$ & + & Gatto et al. (2017) \\
\hline & & 682 households in Jambi province, Sumatra & 2012 & $\mathrm{Y}$ & $\mathrm{N}$ & + & Krishna et al. (2017) \\
\hline & & \multirow[t]{3}{*}{ Summary } & & & $\mathrm{N}=12$ & \multirow{3}{*}{$\begin{array}{c}\mathrm{N}+=11(92 \%) \\
\mathrm{Y}+=2(40 \%) \\
\mathrm{YN}+=1(100 \%)\end{array}$} & \\
\hline & & & & & $Y=5$ & & \\
\hline & & & & & $\mathrm{YN}=1$ & & \\
\hline
\end{tabular}

¥ Oil palm impact on indicator wellbeing: Positive $(+)$, Negative $(-)$

* Whether or not case-control study was conducted: Yes (Y), No (N)

$\S$ Whether or not the majority of communities within study area have relied on subsistence-based livelihoods prior to oil palm development: Yes (Y), No (N), YN (Mixed) 
Table B1. (Continued)

\begin{tabular}{|c|c|c|c|c|c|c|c|}
\hline $\begin{array}{l}\text { Aspect of } \\
\text { wellbeing }\end{array}$ & $\begin{array}{l}\text { Indicator of } \\
\text { wellbeing }\end{array}$ & Study area & Time frame & $\begin{array}{c}\text { Case- } \\
\text { control } \\
\text { study } \\
\nexists\end{array}$ & $\begin{array}{l}\text { Subsistence- } \\
\text { based } \\
\text { livelihoods } \S\end{array}$ & $\begin{array}{l}\text { Oil palm } \\
\text { impact } \ddagger\end{array}$ & Reference \\
\hline \multirow[t]{22}{*}{ Social } & \multirow{19}{*}{$\begin{array}{l}\text { Security, } \\
\text { social equity, } \\
\text { gender } \\
\text { equity }\end{array}$} & 4 communities in West Kalimantan province & 2008 & $\mathrm{~N}$ & $\mathrm{Y}$ & - & Sirait (2009) \\
\hline & & Bungo district, Jambi province, Sumatra & 2007-2009 & $\mathrm{N}$ & $\mathrm{N}$ & - & Rist et al. (2010) \\
\hline & & $\begin{array}{l}\text { Community along Lemanak River and } \\
\text { resettlement site along Tinjar River, Sarawak, Malaysia }\end{array}$ & $1990-2010$ & $\mathrm{~N}$ & Y & - & Cramb \& Sujang (2011) \\
\hline & & 41 households in Bumbun village, Carey Island, Malaysia & 2007 & $\mathrm{~N}$ & Y & - & Lai (2011) \\
\hline & & Pru district, Brong Ahafo, Ghana & 2009 & $\mathrm{~N}$ & Y & - & Schoneveld et al. (2011) \\
\hline & & Dabat village, Sanggau district, West Kalimantan province & 2010 & $\mathrm{~N}$ & $\mathrm{~N}$ & - & Julia \& White (2012) \\
\hline & & Manokwari district, West Papua province & 2011 & $\mathrm{~N}$ & $\mathrm{Y}$ & - & Obidzinski et al. (2012) \\
\hline & & Kubu Raya district, West Kalimantan province & 2011 & $\mathrm{~N}$ & $\mathrm{Y}$ & - & Obidzinski et al. (2012) \\
\hline & & Boven Digoel district, Papua province & 2011 & $\mathrm{~N}$ & Y & - & Obidzinski et al. (2012) \\
\hline & & Jambi province, Sumatra & 2012 & $\mathrm{~N}$ & $\mathrm{~N}$ & - & Manik et al. (2013) \\
\hline & & 3 oil palm estates in Riau province, Sumatra & 2012 & $\mathrm{~N}$ & $\mathrm{~N}$ & - & Sinaga (2013) \\
\hline & & 2 communities in Polochic Valley, Guatemala & $2009-2011$ & $\mathrm{~N}$ & $\mathrm{Y}$ & - & Mingorría et al. (2014) \\
\hline & & 100 municipalities in Colombia & 1993-2009 & Y & YN & - & Castiblanco et al. (2015) \\
\hline & & 4 communities in Berau district, East Kalimantan province & $2005-2010$ & $\mathrm{~N}$ & $\mathrm{~N}$ & - & Elmhirst et al. (2015) \\
\hline & & 1 community in East Kutai district, East Kalimantan province & $2005-2010$ & $\mathrm{~N}$ & Y & - & Elmhirst et al. (2015) \\
\hline & & Meliau, Sanggau district, West Kalimantan province & $2010-2012$ & $\mathrm{~N}$ & $\mathrm{~N}$ & - & $\mathrm{Li}(2015)$ \\
\hline & & Kampung Lebor, Serian, Sarawak, Malaysia & 2012 & $\mathrm{~N}$ & Y & - & Yong \& Pang (2015) \\
\hline & & Coastal villages in West Kalimantan province & $2013-2015$ & $\mathrm{~N}$ & $\mathrm{~N}$ & - & de $\operatorname{Vos}(2016)$ \\
\hline & & 682 households in Jambi province, Sumatra & 2012 & $\mathrm{Y}$ & $\mathrm{N}$ & - & Euler et al. (2017) \\
\hline & & \multirow[t]{3}{*}{ Summary } & & & $\mathrm{N}=8$ & $\mathrm{~N}+=0(0 \%)$ & \\
\hline & & & & & $Y=10$ & $\mathrm{Y}+=0(0 \%)$ & \\
\hline & & & & & $\mathrm{YN}=1$ & $Y N+=0(0 \%)$ & \\
\hline
\end{tabular}

$\ddagger$ Oil palm impact on indicator wellbeing: Positive $(+)$, Negative $(-)$

* Whether or not case-control study was conducted: Yes (Y), No (N)

$\S$ Whether or not the majority of communities within study area have relied on subsistence-based livelihoods prior to oil palm development: Yes (Y), No (N), YN (Mixed) 
Table B1. (Continued)

\begin{tabular}{|c|c|c|c|c|c|c|c|}
\hline $\begin{array}{l}\text { Aspect of } \\
\text { wellbeing }\end{array}$ & $\begin{array}{l}\text { Indicator of } \\
\text { wellbeing }\end{array}$ & Study area & Time frame & $\begin{array}{l}\text { Case- } \\
\text { control } \\
\text { study } \\
\not x\end{array}$ & $\begin{array}{l}\text { Subsistence- } \\
\text { based } \\
\text { livelihoods } \S\end{array}$ & $\begin{array}{l}\text { Oil palm } \\
\text { impact } \ddagger\end{array}$ & Reference \\
\hline \multirow[t]{11}{*}{ Environmental } & $\begin{array}{l}\text { Water, air or } \\
\text { soil quality }\end{array}$ & Beluran district, Sabah, Malaysia & $2007-2008$ & $\mathrm{~N}$ & Y & - & $\begin{array}{l}\text { Dayang Norwana et al. } \\
\text { (2011) }\end{array}$ \\
\hline & & Manokwari district, West Papua province & 2011 & $\mathrm{~N}$ & $Y$ & - & Obidzinski et al. (2012) \\
\hline & & Kubu Raya district, West Kalimantan province & 2011 & $\mathrm{~N}$ & Y & - & Obidzinski et al. (2012) \\
\hline & & Boven Digoel district, Papua province & 2011 & $\mathrm{~N}$ & Y & - & Obidzinski et al. (2012) \\
\hline & & Wilberforce Island, Nigeria & $2013-2014$ & $\mathrm{~N}$ & $\mathrm{~N}$ & - & Ohimain \& Izah (2014) \\
\hline & & Siak watershed, Riau province, Sumatra & $2009-2010$ & $\mathrm{~N}$ & $\mathrm{~N}$ & - & Comte et al. (2015) \\
\hline & & Bungku village, Jambi province, Sumatra & $2013-2014$ & $\mathrm{~N}$ & $\mathrm{~N}$ & - & Merten et al. (2016) \\
\hline & & Kutai Kertanegara district, East Kalimantan province & 2014 & $\mathrm{~N}$ & $\mathrm{~N}$ & - & Dharmawan et al. (2016) \\
\hline & & Summary & & & $\mathrm{N}=4$ & $\mathrm{~N}+=0(0 \%)$ & \\
\hline & & & & & $Y=4$ & $\mathrm{Y}+=0(0 \%)$ & \\
\hline & & & & & $\mathrm{YN}=0$ & $\mathrm{YN}+=\mathrm{NA}$ & \\
\hline
\end{tabular}

$\mp$ Oil palm impact on indicator wellbeing: Positive $(+)$, Negative $(-)$

* Whether or not case-control study was conducted: Yes $(\mathrm{Y})$, No (N)

$\S$ Whether or not the majority of communities within study area have relied on subsistence-based livelihoods prior to oil palm development: Yes (Y), No (N), YN (Mixed) 


\section{References Table B1}

Alwarritzi, W., Nanseki, T. \& Chomei, Y. (2015) Impact of oil palm expansion on farmers' crop income and poverty reduction in Indonesia: An application of propensity score matching. The Journal of Agricultural Science 8, 119.

Budidarsono, S., Dewi, S., Sofiyuddin, M. \& Rahmanulloh, A. (2012) Socioeconomic impact assessment of palm oil production. Technical Brief No. 27. World Agroforestry Centre (ICRAF).

Cahyadi, E.R. \& Waibel, H. (2016) Contract farming and vulnerability to poverty among oil palm smallholders in Indonesia. Journal of Development Studies 52, 681-695.

Castiblanco, C., Etter, A. \& Ramirez, A. (2015) Impacts of oil palm expansion in Colombia: What do socioeconomic indicators show? Land Use Policy 44, 31-43.

Comte, I., Colin, F., Grünberger, O., Whalen, J.K., Widodo, R.H. et al. (2015) Watershed-scale assessment of oil palm cultivation impact on water quality and nutrient fluxes: a case study in Sumatra (Indonesia). Environmental Science and Pollution Research 22, 7676-7695.

Cramb, R. \& Sujang, P.S. (2011) 'Shifting ground': Renegotiating land rights and rural livelihoods in Sarawak, Malaysia. Asia Pacific Viewpoint 52, 136-147.

Dayang Norwana, A.A.B., Kanjappan, R., Chin, M., Schoneveld, G.C., Potter, L. et al. (2011) The local impacts of oil palm expansion in Malaysia; An assessment based on a case study in Sabah State. Center for International Forestry Research (CIFOR) Working Paper No. 78, 1-17.

de Vos, R.E. (2016) Multi-functional lands facing oil palm monocultures: A case study of a land conflict in West Kalimantan, Indonesia. Austrian Journal of South-East Asian Studies 9, 11-32.

Dharmawan, A.H., Mardiyaningsih, D.I. \& Yulian, B.E. (2016) Expansion of oil palm plantation and changes in social, economic and rural ecology: A case study in Kutai Kartanegara. Project Working Paper Series OPAL No. 01/2016.

Elmhirst, R., Siscawati, M. \& Sijapati Basnett, B. (2015) Navigating investment and dispossession: gendered impacts of the oil palm 'land rush' in East Kalimantan, Indonesia. In: Land Grabbing, Conflict and AgrarianEnvironmental Transformations: Perspectives from East and Southeast Asia. Chiang Mai, Thailand.

Euler, M., Krishna, V., Schwarze, S., Siregar, H. \& Qaim, M. (2017) Oil palm adoption, household welfare, and nutrition among smallholder farmers in Indonesia. World Development 93, 219-235.

Feintrenie, L., Chong, W.K. \& Levang, P. (2010) Why do farmers prefer oil palm? Lessons learnt from Bungo district, Indonesia. Small Scale Forestry 9, 379-396.

Gatto, M., Wollni, M., Asnawi, R. \& Qaim, M. (2017) Oil palm boom, contract farming, and rural economic development: Village-level evidence from Indonesia. World Development 95, 127-140.

Julia \& White, B. (2012) Gendered experiences of dispossession: oil palm expansion in a Dayak Hibun community in West Kalimantan. Journal of Peasant Studies 39, 995-1016.

Krishna, V., Euler, M., Siregar, H. \& Qaim, M. (2017) Differential livelihood impacts of oil palm expansion in Indonesia. Agricultural Economics 48, 639-653.

Lai, W.T. (2011) Gender and livelihoods: A case study of the Mah Meri and the oil palm plantations of Carey Island. Asian Journal of Women's Studies 17, 66-95.

Li, T.M. (2015) Social Impacts of Oil Palm in Indonesia: A Gendered Perspective from West Kalimantan. Center for International Forestry Research (CIFOR) Vol. 124.

Manik, Y., Leahy, J. \& Halog, A. (2013) Social life cycle assessment of palm oil biodiesel: a case study in Jambi Province of Indonesia. The International Journal of Life Cycle Assessment 18, 1386-1392.

Merten, J., Röll, A., Guillaume, T., Meijide, A., Tarigan, S. et al. (2016) Water scarcity and oil palm expansion: social views and environmental processes. Ecology and Society 21, 5.

Mingorría, S., Gamboa, G., Martín-López, B. \& Corbera, E. (2014) The oil palm boom: socio-economic implications for Q'eqchi' households in the Polochic valley, Guatemala. Environment, Development and Sustainability 16, 841-871. 
Obidzinski, K., Andriani, R., Komarudin, H. \& Andrianto, A. (2012) Environmental and social impacts of oil palm plantations and their implications for biofuel production in Indonesia. Ecology and Society 17, 25.

Ohimain, E.I., Emeti, C.I. \& Izah, S.C. (2014) Employment and socioeconomic effects of semi-mechanized palm oil mill in Bayelsa state, Nigeria. Asian Journal of Agricultural Extension, Economics and Sociology 3, 206216.

Ohimain, E.I. \& Izah, S.C. (2014) Possible contributions of palm oil mill effluents to greenhouse gas emissions in Nigeria. British Journal of Applied Science \& Technology 4, 4705-4720.

Rist, L., Feintrenie, L. \& Levang, P. (2010) The livelihood impacts of oil palm: smallholders in Indonesia. Biodiversity Conservation 19, 1009-1024.

Schoneveld, G., German, L. \& Nutakor, E. (2011) Land-based investments for rural development? A grounded analysis of the local impacts of biofuel feedstock plantations in Ghana. Ecology and Society 16, 10.

Sinaga, H. (2013) Employment and income of workers on Indonesian oil palm plantations: food crisis at the micro level. Journal of the Science of Food and Agriculture 1, 64-78.

Sirait, M. (2009) Indigenous peoples and oil palm plantation expansion in West Kalimantan, Indonesia. The Hague: Cordaid Memisa.

Susanti, A. \& Burgers, P.P.M. (2011) Oil palm expansion in Riau province, Indonesia: Serving people, planet, profit? The European Report on Development.

Yong, C. \& Pang, W.A. (2015) Gender impact of large-scale deforestation and oil palm plantations among indigenous groups in Sarawak, Malaysia. In: Gender and Land Tenure in the Context of Disaster in Asia (pp. 15-31). Springer International Publishing. 
Table B2. Survey questionnaire in PODES that used to generate the data represented in Table 1.

\begin{tabular}{|c|c|c|}
\hline $\begin{array}{l}\text { Aspect of } \\
\text { well-being }\end{array}$ & Variable (abbreviation) & $\begin{array}{l}\text { Associated survey question in PODES } \\
\text { (original translation in Bahasa Indonesia in italic font) }\end{array}$ \\
\hline \multirow[t]{5}{*}{$\begin{array}{l}\text { Basic } \\
\text { (Living conditions) }\end{array}$} & $\begin{array}{l}\text { Proportions of households with poor housing } \\
\text { conditions (POOR) }\end{array}$ & $\begin{array}{l}\text { Number of households occuring in slums or poor housing neighbourhoods. } \\
\text { Jumlah rumah tangga yang tinggal di pemukiman kumuh. }\end{array}$ \\
\hline & $\begin{array}{l}\text { Proportions of households with electricity } \\
\text { (ELCT) }\end{array}$ & $\begin{array}{l}\text { Number of households with electricity. } \\
\text { Jumlah rumah tangga pengguna listrik. }\end{array}$ \\
\hline & Cooking fuel for majority of households (COOK) & $\begin{array}{l}\text { Cooking fuel for the majority of households. (1=electricity or liquefied petroleum gas (LPG), 2=kerosene, } \\
3=\text { wood or others). } \\
\text { Bahan bakar yang digunakan sebagian besar rumah tangga untuk memasak. (1=listrik atau LPG, } \\
\text { 2=minyak tanah, 3=kayu bakar atau lainnya). }\end{array}$ \\
\hline & $\begin{array}{l}\text { Toilet facilities for majority of households } \\
\text { (TOLT) }\end{array}$ & $\begin{array}{l}\text { Toilet facility for the majority of households. (1=own toilet, } 2=\text { joint toilet, } 3=\text { public toilet, } 4=\text { no toilet). } \\
\text { Tempat buang air besar sebagian besar rumah tangga. (1=jamban sendiri, 2=jamban bersama, 3=jamban } \\
\text { umum, 4=bukan jamban). }\end{array}$ \\
\hline & $\begin{array}{l}\text { Child malnutrition incidence in the last year } \\
\text { (MLNT) }\end{array}$ & $\begin{array}{l}\text { Number of child malnutrition cases in the last year. } \\
\text { Jumlah balita penderita gizi buruk setahun terakhir. }\end{array}$ \\
\hline \multirow[t]{3}{*}{$\begin{array}{l}\text { Physical } \\
\text { (Infrastructure) }\end{array}$} & Distance to nearest healthcare facility (HEAL) & $\begin{array}{l}\text { Distance to the nearest health facilities (hospital, doctor's practice, clinic, public health center, village } \\
\text { health center). } \\
\text { Jarak ke sarana kesehatan terdekat (rumah sakit, praktek dokter, poliklinik, puskesmas, puskesdes). }\end{array}$ \\
\hline & Distance to nearest primary school (PSCH) & $\begin{array}{l}\text { Distance to the nearest primary schools. } \\
\text { Jarak ke Sekolah Dasar }(S D) \text { terdekat. }\end{array}$ \\
\hline & Distance to nearest secondary school (SSCH) & $\begin{array}{l}\text { Distance to the nearest secondary (junior high) schools. } \\
\text { Jarak ke Sekolah Menengah Pertama (SMP) terdekat. }\end{array}$ \\
\hline \multirow[t]{3}{*}{$\begin{array}{l}\text { Financial } \\
\text { (Income support) }\end{array}$} & $\begin{array}{l}\text { Number of active village cooperative schemes } \\
\text { or other schemes (COOP) }\end{array}$ & $\begin{array}{l}\text { Number of cooperative schemes that are actively operated (including KUD, Kopinkra, Kospin, etc). } \\
\text { Jumlah koperasi yang masih aktif beroperasi (termasuk KUD, Kopinkra, Kospin, dII). }\end{array}$ \\
\hline & $\begin{array}{l}\text { Number of credit for farmers or communities } \\
\text { (CRDT) }\end{array}$ & $\begin{array}{l}\text { Number of credit facilities received by communities in the last year (including KUR, KKP, KUK, KPR, etc). } \\
\text { Banyaknya fasilitas kredit yang diterima penduduk selama setahun terakhir (termasuk KUR, KKP, KUK, } \\
K P R, \text { dII). }\end{array}$ \\
\hline & $\begin{array}{l}\text { Number of small industries (<20 employees) } \\
\text { (SIND) }\end{array}$ & $\begin{array}{l}\text { Number of small or micro-scale industry (less than } 20 \text { employees). } \\
\text { Jumlah industri kecil dan mikro (kurang dari } 20 \text { pekerja). }\end{array}$ \\
\hline
\end{tabular}


Table B2. (Continued)

\begin{tabular}{|c|c|c|}
\hline $\begin{array}{l}\text { Aspect of } \\
\text { well-being }\end{array}$ & Variable (abbreviation) & $\begin{array}{l}\text { Associated survey question in PODES } \\
\text { (original translation in Bahasa Indonesia in italic font) }\end{array}$ \\
\hline \multirow{3}{*}{$\begin{array}{l}\text { Social } \\
\text { (Security and social } \\
\text { equity) }\end{array}$} & $\begin{array}{l}\text { Frequency of conflicts among communities in } \\
\text { the last year (CNFL) }\end{array}$ & $\begin{array}{l}\text { Frequency of conflicts among communities in the last year. } \\
\text { Jumlah kejadian perkelahian massal selama setahun terakhir. }\end{array}$ \\
\hline & $\begin{array}{l}\text { Proportion of families with agricultural wage } \\
\text { labourers (AGLB) }\end{array}$ & $\begin{array}{l}\text { Number of families with at least one family member working as an agricultural wage labourer. } \\
\text { Jumlah keluarga yang ada anggota keluarganya menjadi buruh tani. }\end{array}$ \\
\hline & Suicidal rates in the last year (SUIC) & $\begin{array}{l}\text { Number of suicidal victims in the last year. } \\
\text { Banyaknya korban bunuh diri yang terjadi selama setahun terakhir. }\end{array}$ \\
\hline \multirow[t]{3}{*}{$\begin{array}{l}\text { Environmental } \\
\text { (Natural hazard } \\
\text { prevention) }\end{array}$} & Water pollution over the last 3 years (WPOL) & $\begin{array}{l}\text { The occurrence of water pollution in the last year ( } 1=\text { none, } 2=y e s \text { but the issue has not been formally } \\
\text { reported by communities, } 3=y e s \text { and the issue has been formally reported by communities). } \\
\text { Pencemaran air selama setahun terakhir. (1=tidak ada, } 2=\text { ada tetapi tidak ada pengaduan dari } \\
\text { masyarakat, } 3=a d a \text { dan ada pengaduan dari masyarakat). }\end{array}$ \\
\hline & Air pollution over the last 3 years (APOL) & $\begin{array}{l}\text { The occurrence of air pollution in the last year (1=none, } 2=y e s \text { but the issue has not been formally } \\
\text { reported by communities, } 3=y e s \text { and the issue has been formally reported by communities). } \\
\text { Pencemaran udara selama setahun terakhir. (1=tidak ada, } 2=\text { ada tetapi tidak ada pengaduan dari } \\
\text { masyarakat, } 3=\text { ada dan ada pengaduan dari masyarakat). }\end{array}$ \\
\hline & $\begin{array}{l}\text { Frequency of floods and landslides over the last } \\
3 \text { years (FLOD) }\end{array}$ & $\begin{array}{l}\text { Frequency of floods, flash floods, or landslides in the last three years. } \\
\text { Banyaknya kejadian banjir, banjir banding, dan tanah longsor selama tiga tahun terahkir. }\end{array}$ \\
\hline
\end{tabular}


Table B3. The use of PODES data in studies on socioeconomic and developments across Indonesia (in alphabetical order of references).

\begin{tabular}{|c|c|c|c|c|}
\hline \multirow[t]{2}{*}{ References } & \multicolumn{2}{|l|}{ Study } & \multicolumn{2}{|l|}{ Use of PODES data } \\
\hline & Scope & Area & Year & Aspect \\
\hline Barron et al. (2016) & Distributions of conflicts & Indonesia & 2003 & $\begin{array}{l}\text { Population demographics, economic, } \\
\text { institutional }\end{array}$ \\
\hline Barron et al. (2009) & Characteristics of social conflicts & Indonesia & 2003 & $\begin{array}{l}\text { Population demographics, economic, } \\
\text { institutional }\end{array}$ \\
\hline Budidarsono et al. (2012) & Socioeconomic impact of oil palm & Indonesia & 2008 & Social, economic, infrastructure \\
\hline Cameron \& Shah (2013) & Social impact of cash transfer programs & Indonesia & 2006 & $\begin{array}{l}\text { Population demographics, social, } \\
\text { economic }\end{array}$ \\
\hline Cameron \& Shah (2015) & $\begin{array}{l}\text { Risk-taking behaviour given exposure to } \\
\text { natural disaster }\end{array}$ & Indonesia & 2008 & Social, economic, environment \\
\hline Cooley et al. (2016) & $\begin{array}{l}\text { Impact of maternal undernutrition } \\
\text { on child health }\end{array}$ & Indonesia & 2011 & Social, infrastructure \\
\hline De Juan et al. (2015) & Religious conflicts & Indonesia & 2003 & Social \\
\hline Grimm et al. (2015) & Impact of electricity on fertility & Indonesia & $\begin{array}{l}\text { 1996, 2000, 2003, } \\
2006,2008\end{array}$ & Infrastructure, livelihood \\
\hline Hasan et al. (2013) & Early education and development & Indonesia & $\begin{array}{l}\text { 2003, 2006, 2008, } \\
2011\end{array}$ & $\begin{array}{l}\text { Population demographics, social, } \\
\text { infrastructure }\end{array}$ \\
\hline Hashiguchi \& Higasikata (2017) & Human capital externalities & Indonesia & 1996,2006 & Social, economic, infrastructure \\
\hline Jagger \& Rana (2017) & Impact of REDD+ on social welfare & Kalimantan & 2008,2011 & Infrastructure, land use \\
\hline Korkeala \& Obidzinski (2012) & Oil-palm expansion and household welfare & Kalimantan & 2003 & Land use \\
\hline Lewis (2016) & $\begin{array}{l}\text { Impact of local political fragmentation on fiscal } \\
\text { and service }\end{array}$ & Indonesia & $\begin{array}{l}2003,2006,2008, \\
2011,2014\end{array}$ & Social, economic, infrastructure \\
\hline Maharani \& Tampubolon (2014) & $\begin{array}{l}\text { Impact of fiscal decentralisation on child } \\
\text { immunisation }\end{array}$ & Indonesia & 2011 & $\begin{array}{l}\text { Population demographics, economic, } \\
\text { infrastructure }\end{array}$ \\
\hline Makovec et al. (2016) & $\begin{array}{l}\text { Impact of restrictive emigration policies on } \\
\text { social welfare }\end{array}$ & Indonesia & 2006 & $\begin{array}{l}\text { Population demographics, social, } \\
\text { economic }\end{array}$ \\
\hline Miguel et al. (2005) & Impact of social capital on industrialization & Indonesia & 1986 & $\begin{array}{l}\text { Population demographics, social, } \\
\text { economic, institutional }\end{array}$ \\
\hline Miteva et al. (2015) & $\begin{array}{l}\text { Impact of forest management certification on } \\
\text { human wellbeing }\end{array}$ & Kalimantan & $2000,2006,2008$ & $\begin{array}{l}\text { Population demographics, infrastructure, } \\
\text { land use }\end{array}$ \\
\hline Liu \& Yamauchi (2014) & Impact of population growth on income & Indonesia & 2000,2006 & Infrastructure, environment \\
\hline Olsson \& Valsecchi (2015) & $\begin{array}{l}\text { Impact of fiscal decentralisation on economic } \\
\text { and social welfare }\end{array}$ & Indonesia & $2003,2006,2008$ & Infrastructure \\
\hline
\end{tabular}


Table B3. (Continued)

\begin{tabular}{|c|c|c|c|c|}
\hline \multirow[t]{2}{*}{ References } & \multicolumn{2}{|l|}{ Study } & \multicolumn{2}{|l|}{ Use of PODES data } \\
\hline & Scope & Area & Year & Aspect \\
\hline Parmanto et al. (2008) & $\begin{array}{l}\text { Multidimensional visualization of village health } \\
\text { statistics }\end{array}$ & Indonesia & 2003 & Social, environment \\
\hline Rokx (2010) & Provision of health services & Indonesia & 1996, 2006 & $\begin{array}{l}\text { Population demographics, social, } \\
\text { infrastructure }\end{array}$ \\
\hline Sparrow (2008) & Effectiveness of health card programs & Indonesia & 1996 & Social, economic, infrastructure \\
\hline Sparrow \& Pradhan (2014) & $\begin{array}{l}\text { Efficiency of district's public health and education } \\
\text { programs }\end{array}$ & Indonesia & $2003,2006,2008$ & Population demographics, infrastructure \\
\hline Sujarwoto \& Tampubolon (2016) & Access to internet facilities & Indonesia & 2011 & $\begin{array}{l}\text { Population demographics, economic, } \\
\text { infrastructure }\end{array}$ \\
\hline Sugiarto et al. (2017) & $\begin{array}{l}\text { Impact of climate change on water resources and } \\
\text { agriculture }\end{array}$ & East Java & 2014 & $\begin{array}{l}\text { Economic, infrastructure, land use, } \\
\text { environment }\end{array}$ \\
\hline Tan Soo (2017) & Valuation of air quality & Indonesia & 2006 & Economic \\
\hline Vothknech \& Sumarto (2011) & Impact of violent conflicts on economic growth & Indonesia & 2003, 2006, 2008 & Social, economic \\
\hline Widayati et al. (2014) & Livelihoods and access to clean water & South Sulawesi & 2011 & $\begin{array}{l}\text { Population demographics, social, } \\
\text { economic }\end{array}$ \\
\hline Yamauchi et al. (2009) & Dynamics of village economies & Indonesia & 1996,2006 & Infrastructure \\
\hline
\end{tabular}




\section{References Table B3}

Barron, P., Jaffrey, S. \& Varshney, A. (2016) When large conflicts subside: The ebbs and flows of violence in post-Suharto Indonesia. Journal of East Asian Studies 16, 191-217.

Barron, P., Kaiser, K. \& Pradhan, M. (2009) Understanding variations in local conflict: Evidence and implications from Indonesia. World Development 37, 698-713.

Budidarsono, S., Dewi, S., Sofiyuddin, M. \& Rahmanulloh, A. (2012) Socioeconomic Impact Assessment of Palm Oil Production. Technical Brief No. 27: palm oil series. Bogor, Indonesia. World Agroforestry Centre (ICRAF), SEA Regional Office.

Cameron, L. \& Shah, M. (2013) Can mistargeting destroy social capital and stimulate crime? Evidence from a cash transfer program in Indonesia. Economic Development and Cultural Change 62, 381-415.

Cameron, L. \& Shah, M. (2015) Risk-taking behavior in the wake of natural disasters. The Journal of Human Resources 50, 484-515.

Cooley, P.C., Poulos, C., Rineer, J.I., Rogers, S.M., Scruggs, M.D. et al. (2016) Forecasting the Impact of Maternal Undernutrition on Child Health Outcomes in Indonesia. RTI Press Publication No. RR-0028-1612. Research Triangle Park, NC: RTI Press.

De Juan, A., Pierskalla, J.H. \& Vüllers, J. (2015) The pacifying effects of local religious institutions: An analysis of communal violence in Indonesia. Political Research Quarterly 68, 211-224.

Grimm, M., Sparrow, R. \& Tasciotti, L. (2015) Does electrification spur the fertility transition? Evidence from Indonesia. Demography 52, 1773-1796.

Hasan, A., Hyson, M. \& Chang, M.C. (2013) Early Childhood Education and Development in Poor Villages of Indonesia: Strong Foundations, Later Success. World Bank Publications (2013).

Hashiguchi, Y. \& Higashikata, T. (2017) Human Capital Externalities in Indonesian Cities. IDE Discussion Paper No. 672. Institute of Developing Economies, Japan External Trade Organization (JETRO).

Jagger, P. \& Rana, P. (2017) Using publicly available social and spatial data to evaluate progress on REDD+ social safeguards in Indonesia. Environmental Science and Policy 76, 59-69.

Korkeala, O. \& Obidzinski, K. (2012) A Household Welfare Perspective on The Expansion of Palm Oil Production in Indonesia. Economics Department Working Paper Series No. 4212. University of Sussex.

Lewis, B.D. (2016) Local Political Fragmentation: Fiscal and Service Delivery Effects in Indonesia. Working Papers in Trade and Development No. 2016/16. ANU College of Asia and the Pacific, The Australian National University.

Liu, Y. \& Yamauchi, F. (2014) Population density, migration, and the returns to human capital and land: Insights from Indonesia. Food Policy 48, 182-193.

Maharani, A. \& Tampubolon, G. (2014) Has decentralisation affected child immunisation status in Indonesia? Global Health Action 7, 24913.

Makovec, M., Purnamasari, R., Sandi, M. \& Savitri, A. (2016) Intended vs. Unintended Consequences of Migration Restriction Policies: Evidence from a Natural Experiment in Indonesia (No. 2016-13). ISER Working Paper Series.

Miguel, E., Gertler, P. \& Levine, D.I. (2005) Does social capital promote industrialization? Evidence from a rapid industrializer. The Review of Economics and Statistics 87, 754-762.

Miteva, D.A., Loucks, C.J. \& Pattanayak, S.K. (2015) Social and environmental impacts of forest management certification in Indonesia. PLoS One 10, e0129675.

Olsson, O. \& Valsecchi, M. (2015) Resource Windfalls and Local Government Behavior: Evidence from a Policy Reform in Indonesia. Working Papers in Economic No. 635. University of Gothenburg.

Parmanto, B., Paramita, M.V., Sugiantara, W., Pramana, G., Scotch, M. et al. (2008) Spatial and multidimensional visualization of Indonesia's village health statistics. International Journal of Health Geographics 7, 30. 
Rokx, C. (2010) New Insights into the Provision of Health Services in Indonesia: A Health Workforce Study. World Bank Publications.

Sparrow, R. (2008) Targeting the poor in times of crisis: the Indonesian health card. Health Policy and Planning 23, 188-199.

Sparrow, R. \& Pradhan, M. (2014) Activity Measures for Health and Education Outcomes in Indonesia. TNP2K Working Paper 15-2014. Jakarta, Indonesia: Tim Nasional Percepatan Penanggulangan Kemiskinan (TNP2K).

Sugiarto, Y., Atmaja, T. \& Wibowo, A. (2017) Developing vulnerability analysis method for climate change adaptation on agropolitan region in Malang district. IOP Conference Series: Earth and Environmental Science 58, 012044. IOP Publishing.

Sujarwoto, S. \& Tampubolon, G. (2016) Spatial inequality and the Internet divide in Indonesia 2010-2012. Telecommunication Policy 40, 602-616.

Tan Soo, J.S. (2017) Valuing air quality in Indonesia using households' locational choices. Environmental and Resource Economics,1-22.

Vothknecht, M. \& Sumarto, S. (2011) Beyond the Overall Economic Downturn: Evidence on Sector-Specific Effects of Violent Conflict from Indonesia. DIW Discussion Papers No. 1105.

Widayati, A., Khasanah, N., Prasetyo, P.N. \& Dewi, S. (2014) Upland Landscape Management for Drinking Water Provision-Biang Loe Catchment, Bantaeng, South Sulawesi. AgFor Livelihood Conservation Strategy 01. Bogor, Indonesia. World Agroforestry Centre (ICRAF) Southeast Asia Regional Program.

Yamauchi, F., Muto, M., Chowdhury, S., Dewina, R. \& Sumaryanto, S. (2009) Spatial Networks, Labor Supply, and Income Dynamics. IFPRI Discussion Papers No. 897. 
Table B4. PODES censuses used to assess the change in village well-being (indicated in check marks) over varying plantation ages: $2-3,6-8$, and $11-14$ years, and the number villages included as treatment units and control units for each time period of analysis.

\begin{tabular}{|c|c|c|c|c|c|c|c|c|c|}
\hline \multirow{2}{*}{$\begin{array}{l}\text { Plantation } \\
\text { age }\end{array}$} & \multirow{2}{*}{$\begin{array}{l}\text { Analysis } \\
\text { time frame }\end{array}$} & \multicolumn{6}{|c|}{ PODES census year } & \multicolumn{2}{|c|}{ Number of unit } \\
\hline & & 2000 & 2003 & 2006 & 2008 & 2011 & 2014 & Treated & Control \\
\hline \multirow[t]{5}{*}{$2-3$ years } & $2000-2003$ & $\mathrm{v}$ & $\mathrm{V}$ & & & & & 100 & 5673 \\
\hline & 2003-2006 & & $v$ & $\mathrm{v}$ & & & & 51 & 5579 \\
\hline & $2006-2008$ & & & $\mathrm{v}$ & $\mathrm{v}$ & & & 116 & 5241 \\
\hline & 2008-2011 & & & & $\mathrm{v}$ & $\mathrm{v}$ & & 343 & 5170 \\
\hline & 2011-2014 & & & & & $\mathrm{v}$ & $\mathrm{v}$ & 70 & 4829 \\
\hline \multirow[t]{5}{*}{$6-8$ years } & $2000-2006$ & $\mathrm{v}$ & & $\mathrm{v}$ & & & & 100 & 5673 \\
\hline & $2000-2008$ & $\mathrm{v}$ & & & $\mathrm{v}$ & & & 99 & 5223 \\
\hline & 2003-2011 & & $\mathrm{v}$ & & & $\mathrm{v}$ & & 50 & 5168 \\
\hline & 2006-2014 & & & $\mathrm{v}$ & & & $\mathrm{v}$ & 116 & 4827 \\
\hline & 2008-2014 & & & & $\mathrm{V}$ & & $\mathrm{v}$ & 70 & 4829 \\
\hline \multirow[t]{3}{*}{ 11-14 years } & $2000-2011$ & $\mathrm{v}$ & & & & $\mathrm{V}$ & & 99 & 5153 \\
\hline & 2003-2014 & & $\mathrm{v}$ & & & & $\mathrm{v}$ & 50 & 4826 \\
\hline & $2000-2014$ & $\mathrm{v}$ & & & & & $\mathrm{v}$ & 99 & 4812 \\
\hline
\end{tabular}

Table B5. The robustness of the matching analysis against hidden bias due to an unobserved confounder, as indicated by the minimum value of the sensitivity parameter $\Gamma_{\mathrm{C}}$ across wellbeing indicators, for the overall analysis and each of the livelihood subgrouping analysis (subsistence-based livelihoods and market-oriented livelihoods), for each time period. $\Gamma_{\mathrm{C}}=1$ means that unobserved confounder needs to be at least as strong as the included effects to have an influence. Thus, larger $\min \left(\Gamma_{c}\right)$ indicates a more robust analysis against hidden bias.

\begin{tabular}{ccc}
\hline $\begin{array}{c}\text { Analysis type according to } \\
\text { plantation age }\end{array}$ & $\begin{array}{c}\text { Analysis } \\
\text { time frame }\end{array}$ & $\min \left(\Gamma_{\mathrm{c}}\right)$ \\
\hline $2-3$ years & $2000-2003$ & 2.24 \\
& $2003-2006$ & 1.88 \\
\hline & $2006-2008$ & 1.74 \\
\hline $6-8$ years & $2008-2011$ & 2.16 \\
\hline & $2011-2014$ & 1.98 \\
\hline & $2000-2006$ & 1.82 \\
& $2000-2008$ & 2.01 \\
\hline $11-14$ years & $2003-2011$ & 1.92 \\
& $2006-2014$ & 1.72 \\
& $2008-2014$ & 2.06 \\
\hline & $2000-2011$ & 2.11 \\
& $2003-2014$ & 1.94 \\
\hline & $2000-2014$ & 2.04 \\
\hline
\end{tabular}

